\title{
The high resolution bathymetric map of the exhalative area of Panarea (Aeolian Islands, Italy)
}

\author{
Marco Anzidei $\left({ }^{1}\right)$, Alessandra Esposito $\left({ }^{1}\right)$, Giovanni Bortoluzzi $\left({ }^{2}\right)$ and Francesco De Giosa $\left({ }^{3}\right)$ \\ (') Istituto Nazionale di Geofisica e Vulcanologia, Roma, Italy \\ (2) Istituto di Geologia Marina (ISMAR), CNR, Bologna, Italy \\ $\left(^{3}\right)$ Coastal Consulting and Exploration srl, Bari, Italy
}

\begin{abstract}
On November 3, 2002 a shallow submarine gas eruption occurred in an area of $2.3 \mathrm{~km}^{2}$ east of Panarea (Aeolian volcanic arc, Southern Thyrrenian Sea, Italy). The exhalative area, surrounded by the islets of Dattilo, Panarelli, Lisca Bianca, Bottaro and Lisca Nera, has been known since historical times for the hydrothermal activity related to the Panarea volcanic complex. Due to the exceptional characteristics of the phenomenon, different geological, geochemical, geophysical and studies were carried out in this still poorly known volcanic area. A particular effort was devoted to producing a high resolution bathymetric map that also aimed to estimate the amount and location of the active exhalative centers and their variations in space and time. Data were obtained by three RTK multibeam surveys performed between December 2002 and December 2003. Here we show and discuss the technical details of the bathymetric surveys, the bathymetric map at $0.5 \mathrm{~m}$ resolution, and the accurate location of the 606 main exhalative centres active during the 2002-2003 crisis. The bathymetric data and the maps show two prevailing principal NE-SW and NW-SE alignments that match the spatial distribution of the exhalation centres. The accurate positioning at submeter accuracy of the gas vents is useful in the monitoring activity and to study their temporal and spatial variability.
\end{abstract}

Key words Panarea - bathimetry - DEM - hydrotermal systems

\section{Introduction}

Panarea Island is located in the Southern Tyrrhenian Sea and is part of the volcanic arc of the Aeolian Islands that is made up of seven islands, some minor islets and several seamounts (fig. 1a). The area is characterized by a complex geodynamics (Falsaperla et al., 1999) being affected by shallow to deep seismicity due

Mailing address: Dr. Marco Anzidei, Istituto Nazionale di Geofisica e Vulcanologia, Via di Vigna Murata 605, 00143 Roma, Italy, e-mail: anzidei@ingv.it to a slab deepening under the Calabrian Arc (Chiarabba et al., 2005), active crustal deformation (Anzidei et al., 2000; Hollenstein et al., 2003; Tallarico et al., 2003; D'Agostino and Selvaggi, 2004; Serpelloni et al., 2005), active volcanoes (Lipari, Vulcano and Stromboli) and hydrothermalism. The above features witness a long lasting activity, as described by Italiano and Nuccio (1991), Gamberi et al. (1997), Calanchi et al. (1999, 2002), De Astis et al. (2003) and Caliro et al. (2004).

Panarea is the smallest among the Aeolian Islands, representing the subaerial portion of a submarine stratovolcano about $2000 \mathrm{~m}$ high and $20 \mathrm{~km}$ wide (Gabbianelli et al., 1993; Gamberi et al., 1997). East of Panarea, the islets of Basiluzzo, Dattilo, Panarelli, Lisca Bianca, Bottaro, Lisca Nera and Le Formiche (hereafter referred as the 'Islets') form an archipelago that 


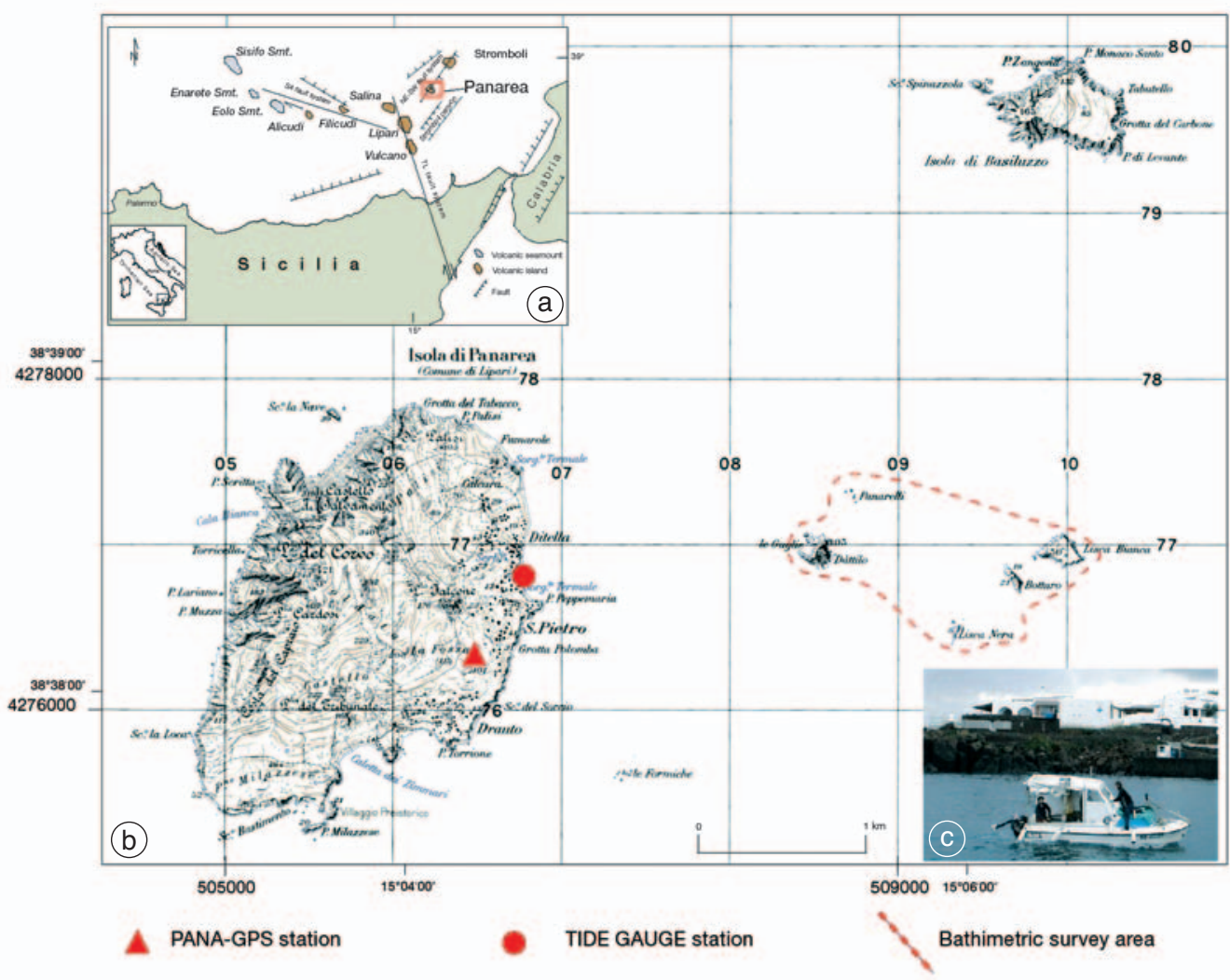

Fig. 1a-c. a) Regional setting of Panarea Island; b) Panarea Archipelago; c) the ALSEA vessel used during bathymetric surveys. In the map are also displayed the locations of the tide gauge, the TyrGeoNet GPS station and the area investigated by the bathymetric surveys.

emerges from the eastern flank of the volcano (fig. 1b). Panarea is made up of dacite to rhyolite lava domes, dated up to $149 \pm 5 \mathrm{kyr}$ (Calanchi et al., 1999), interbedded with pyroclastic deposits. The island is topped by the pyroclastic deposits of Punta del Torrione formation, dated between $42 \mathrm{kyr}$ and $11 \mathrm{kyr}$, which also outcrop at Salina, Lipari, Filicudi, Vulcano and along the northern coast of Calabria and Sicily (Lucchi et al., 2003).

Boiling of the sea-water has been described since historical times in the Aeolian Islands by Titus Livius, Strabo, Julis Obsequens, Orosius Palulus, Posidonius and Plinius the Elder (SGA, 1993). An event that produced sudden changes in the sea level, hot steam from sea surface, stinky air, death of fishes, mud emerging from seafloor occurred on 126 b.C. This event is likely referred to the formation of Vulcanello, nowadays linked to Vulcano Island. The exhalative activity at Panarea has been described by Houel (1782), Dolomieu (1783), Ferrara (1810), Spallanzani (1825), Dumas (1860), Mercalli (1883), Luigi Salvatore d'Austria (1895), Romano (1973), Italiano and Nuccio (1991), Gabbianelli et al. (1990), Calanchi et al. (1995), Anzidei (2000), Caliro et al., (2004), Caracausi et al. (2005).

At the beginning of November 2002, during the eruptions of Etna and Stromboli volcanoes, a submarine gas eruption started in a shallow area up to $30 \mathrm{~m}$ water depth and $2.3 \mathrm{~km}^{2}$ of surface, bordered by the Islets. The event occurred 
suddenly, without significant seismicity (Saccarotti et al., 2003) and reached an intensity level never observed before during the last century (SGA, 1996). The gas output was estimated to be $10^{9} 1 /$ day, two orders of magnitude higher than that previously measured (Caliro et al., 2004). The most active exhalation center (EC-1, fig. 7b) was located close to the SW wall of the islet of Bottaro, with gas flowing vigorously up to the water surface. To provide the present day locations of the submarine gas Exhalation Centres (EC) with respect to previous studies (Gabbianelli et al., 1990; Anzidei, 2000) and a first high resolution morphobathymetric map of the exhalation centres, bathymetric surveys were planned and performed during the maximum activity. Surveys were carried out in the early days of December 2002, with partial repetitions in selected areas during July 2003 and December 2003.

\section{Bathymetric surveys}

A multibeam high resolution survey that covered an area of about $9 \mathrm{~km}^{2}$ around the Islets was performed for the first time in December 812, 2002, using the Alsea boat of Coastal Consulting and Exploration Company (fig. 1c), equipped with an ultra high resolution Reson Seabat 8125 multibeam (240 beams, $120^{\circ}$ sector coverage, $455 \mathrm{kHz}$ ) (table I).

Before starting the surveys, a check of the health of the GPS/RTK data link was performed

Table I. Instrumentation used during the bathymetric surveys.

\begin{tabular}{|c|c|c|}
\hline Instrumentation & Type & Features \\
\hline Vessel & M/B ALSEA & - \\
\hline $\begin{array}{l}\text { Differential GPS receiver } \\
\text { (RTK mode) }\end{array}$ & Ashtech-Aquarius 02 & $\begin{array}{l}10 \mathrm{~mm}+0.5 \mathrm{ppm}, X Y \\
20 \mathrm{~mm}+1.0 \mathrm{ppm}, Z\end{array}$ \\
\hline Multi beam & Reson SeaBat 8125 & $\begin{array}{c}\text { Frequency } 455 \mathrm{kHz} \\
\text { Angle } 120^{\circ} \\
\text { Beams } 240 \\
\text { Max depth } 120 \mathrm{~m} \\
\text { Resolution } 6 \mathrm{~mm}\end{array}$ \\
\hline Gyrocompass & SG Brown Meridian & $\begin{array}{c}0.05^{\circ} \text { static secant latitude } \\
0.2^{\circ} \text { dynamic secant latitude }\end{array}$ \\
\hline Velocity sounder & Navitronic SVP 15 & $\begin{array}{l}\text { Resolution } 0.1 \mathrm{~m} / \mathrm{s} \\
\text { Accuracy } \pm 0.25 \mathrm{~m} / \mathrm{s}\end{array}$ \\
\hline CTD & Microcat SBE 37-SI & $\begin{array}{c}\text { Conductivity accuracy } 0.0003 \mathrm{~S} / \mathrm{m} \\
\text { Temperature accuracy } 0.002^{\circ} \mathrm{C}\end{array}$ \\
\hline \multirow[t]{2}{*}{ Motion sensor } & TSS DMS 2-05 & $\begin{array}{c}\text { Waves } \\
\text { Static accuracy } 5 \mathrm{~cm} \\
\text { Dynamic accuracy } 0 \div 20 \mathrm{~s} \text { period }\end{array}$ \\
\hline & & $\begin{array}{c}\text { Pitch and roll } \\
\text { Static accuracy } 0.025^{\circ} \\
\text { Dynamic accuracy } 0.03^{\circ} \pm 5^{\circ}\end{array}$ \\
\hline $\begin{array}{l}\text { Digital tide gauge } \\
\text { (at Panarea) }\end{array}$ & $\begin{array}{l}\text { Ott Hydrometry } \\
\text { Orphimedes }\end{array}$ & Accuracy $<1 \mathrm{~cm}$ \\
\hline On board computers & $\begin{array}{c}\text { Pentium IV- } \\
\text { Windows } 2000\end{array}$ & Data acquisition \\
\hline Software & RESON B.V. PDS 2000 & Navigation and data analysis \\
\hline Software & CARIS-HIPS 5.2 & Data analysis \\
\hline Software & ArcView GIS 8.2 & Data management \\
\hline
\end{tabular}




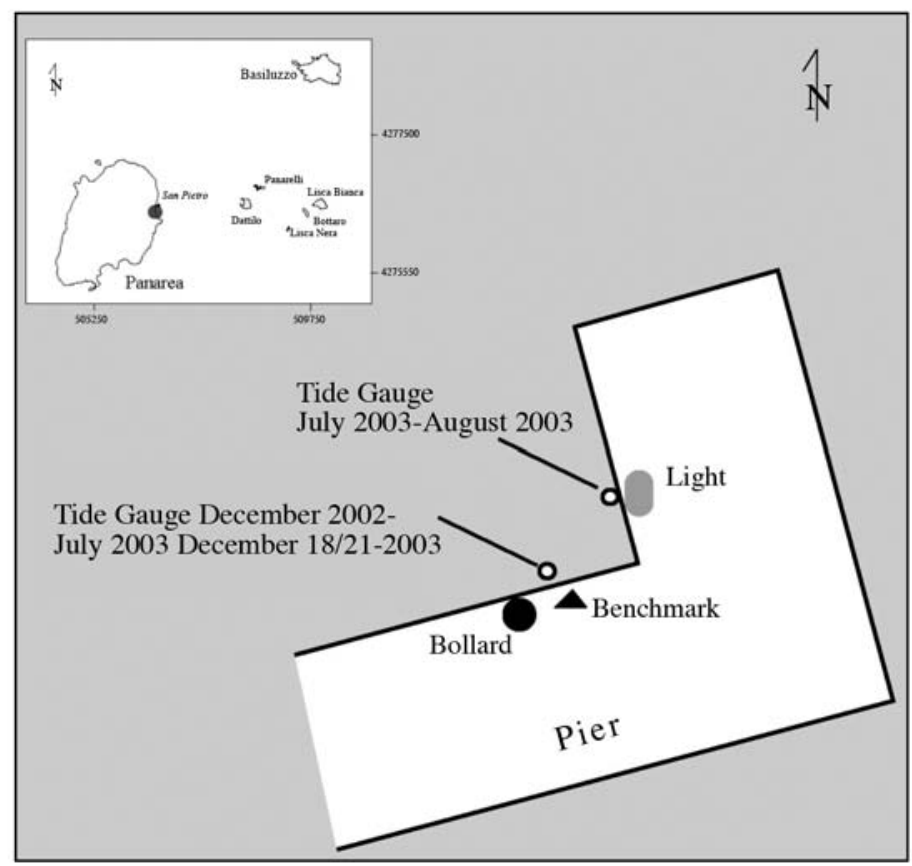

Fig. 2. Sketch (not in scale) of the Panarea Pier with the location of the tide gauge and the geodetic benchmark used to define its coordinates with respect to the TyrGeoNet GPS station of Panarea.

Table II. Coordinates of PANA TyrGeoNet station and tide gauge benchmark (WGS84, ellipsoidal heights).

\begin{tabular}{|c|c|c|c|}
\hline Station & Geographic & UTM & Height (m) \\
\hline PANA (TyrGeoNet) & $\begin{array}{c}\text { Lat N } 38^{\circ} 37^{\prime} 58.909 \\
\text { Long E } 15^{\circ} 04^{\prime} 26.457\end{array}$ & $\begin{array}{l}\text { N } 4276057.468 \\
\text { E } 506442.1583\end{array}$ & 144554 \\
\hline Tide Gauge & $\begin{array}{l}\text { Lat N } 38^{\circ} 38^{\prime} 16.772 \\
\text { Long E } 15^{\circ} 04^{\prime} 40.257\end{array}$ & $\begin{array}{c}\text { N } 4276608.335 \\
\text { E } 506775.313\end{array}$ & 43.30 \\
\hline
\end{tabular}

throughout the planned survey, having previously found a local shadow area behind the eastern wall of Dattilo. The bathymetric datum was established by measuring the sea level through a high accuracy tide gauge, temporarily installed along the pier at S. Pietro, Panarea (fig. 1a and 2). The instrumental height of the zero level was referred to a WGS84 geodetic benchmark previously set up over the pier (fig. 2 and table II). The latter was measured by geodetic space techniques using a couple of dual frequency GPS receivers and by ground meas- urements using a Total Station, with reference to the GPS geodetic monument of PANA, located at Panarea (fig. 1a), which belongs to the Tyrrhenian Geodetic Network (TyrGeoNet), whose 3D coordinates are known at a few mm level (Anzidei et al., 1995; Serpelloni et al., 2005), (table II).

The decimetric positioning of the vessel was computed by GPS technique in RTK mode. Real time coordinates were obtained by installing an Ashtech Aquarius reference station located on the GPS station PANA and transmit- 


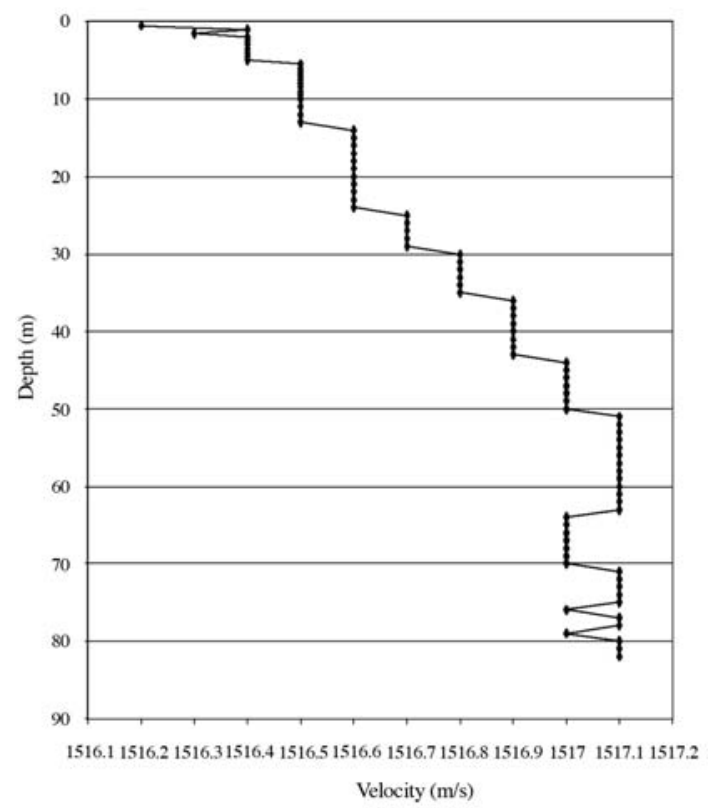

Fig. 3. Sound speed profile. Data were used to calibrate the multibeam system for sound speed velocity in the water to determine depths at $1 \mathrm{~cm}$ formal accuracy. ting the differential corrections by a High Frequency link at $1 \mathrm{~Hz}$ rate to the mobile Aquarius receiver which was placed on board of the vessel. In addition to this, a Sg-Brown Meridian Surveyor gyrocompass, a Tss DM505 MRU and a Fugro Omnistar Differential GPS, were interfaced to the Reson PDS2000 Navigation software (www.reson.com) for data acquisition (multibeam and positioning), control, calibration and pre-processing. A SBE 37-SI Microcat CTD probe was located at the sonar head and interfaced to the sonar processor, so providing the real time speed of sound data for the beam forming, while the Navitronics SVP15 and a SeaBird CTD probes were also used for profiling the speed of sound along the water column (fig. 3). Additional details on the instrumentation are reported in table I.

Navigation routes were planned with the aim to achieve the full coverage of the sea bottom (fig. 4), with at least $20-30 \%$ overlap of the nearby swaths. The Reson PDS2000 software was able to show in real time to the operator and the pilot the ongoing multibeam and Digital Terrain Model (DTM) and the positioning information that were used for guidance.

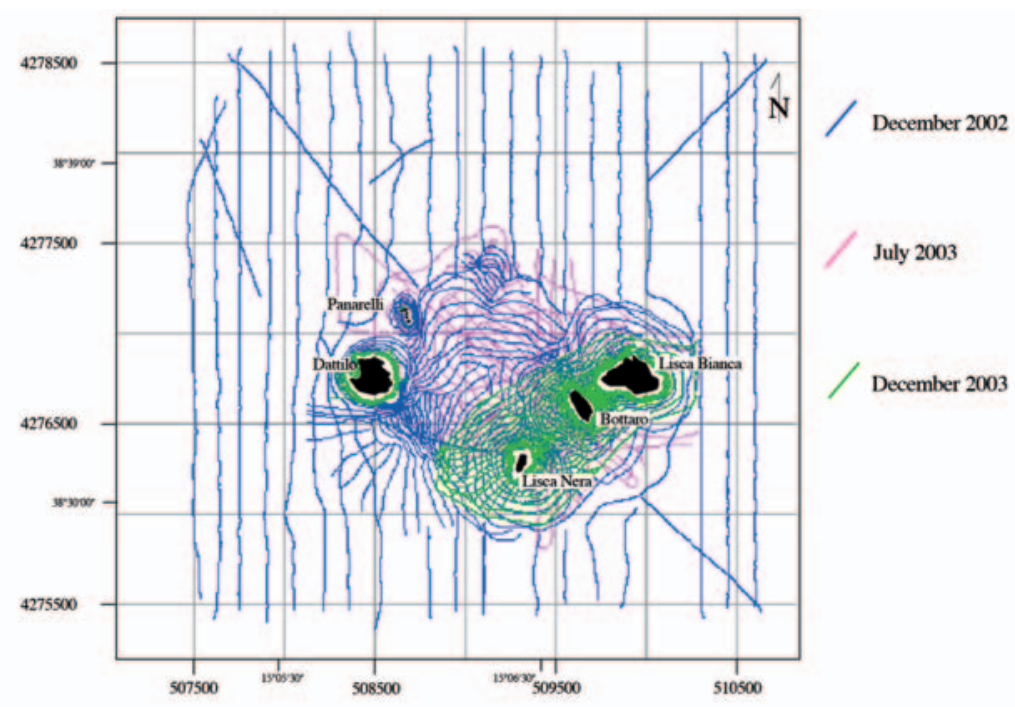

Fig. 4. Course over the ground performed by ALSEA vessel during bathymetric surveys. The $30 \%$ overlapping between nearby lines guarantee the full coverage of the area. 
At the beginning of each survey, a full set of multibeam calibration lines were acquired, on flat bottoms and steep targets at 30-70 m water depth. The roll, pitch and yaw correction angles were then used to correct the installation geometries. Calibration parameters were taken into account during data analysis to correct the observations.

\section{Data analysis, bathymetric map and exhalation centres}

Data analysis was performed by the Computer Aided Resource Information SystemHydrographic Information Processing System (CARIS-HIPS) Pro v. 5.2 software (CARIS,
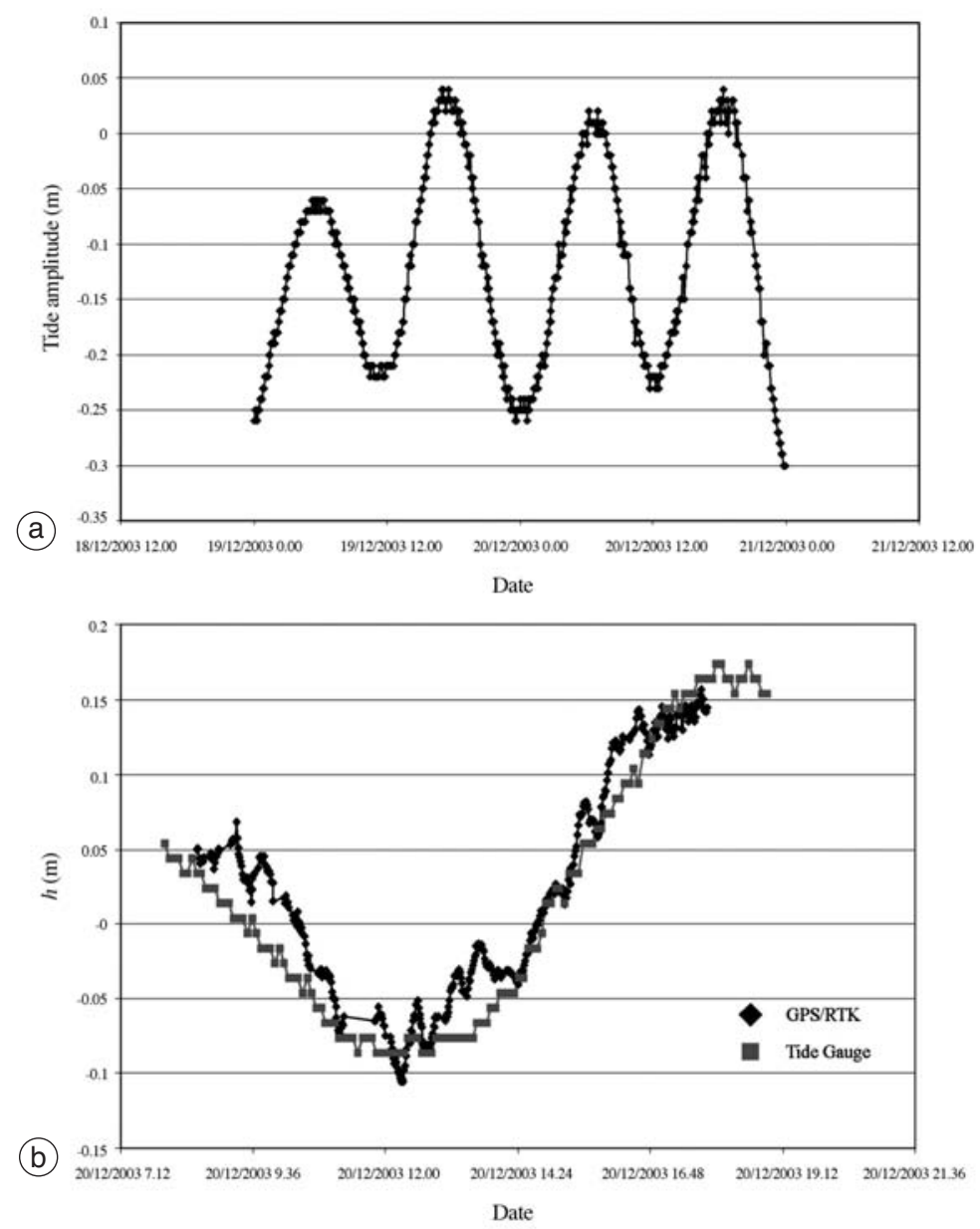

Fig. 5a,b. a) Example of tide gauge recordings collected at 5 min sampling rate at Panarea Pier in the time span December 19-21, 2003 during bathymetric surveys. Tide amplitudes are $<0.4 \mathrm{~m}$, typical of the Central Mediterranean Sea. b) Comparison between tide data recorded by the tide gauge located at Panarea (grey line) and those registered by the GPS/RTK system located on board of the vessel (black line) during bathymetric surveys. The GPS/RTK tide data have been collected at 1 min sampling rate but averaged at 10 min to remove the high frequency noise. The two data sets are in good agreement. Tidal values were used to correct depth measurements, that were reduced to a mean sea level. 

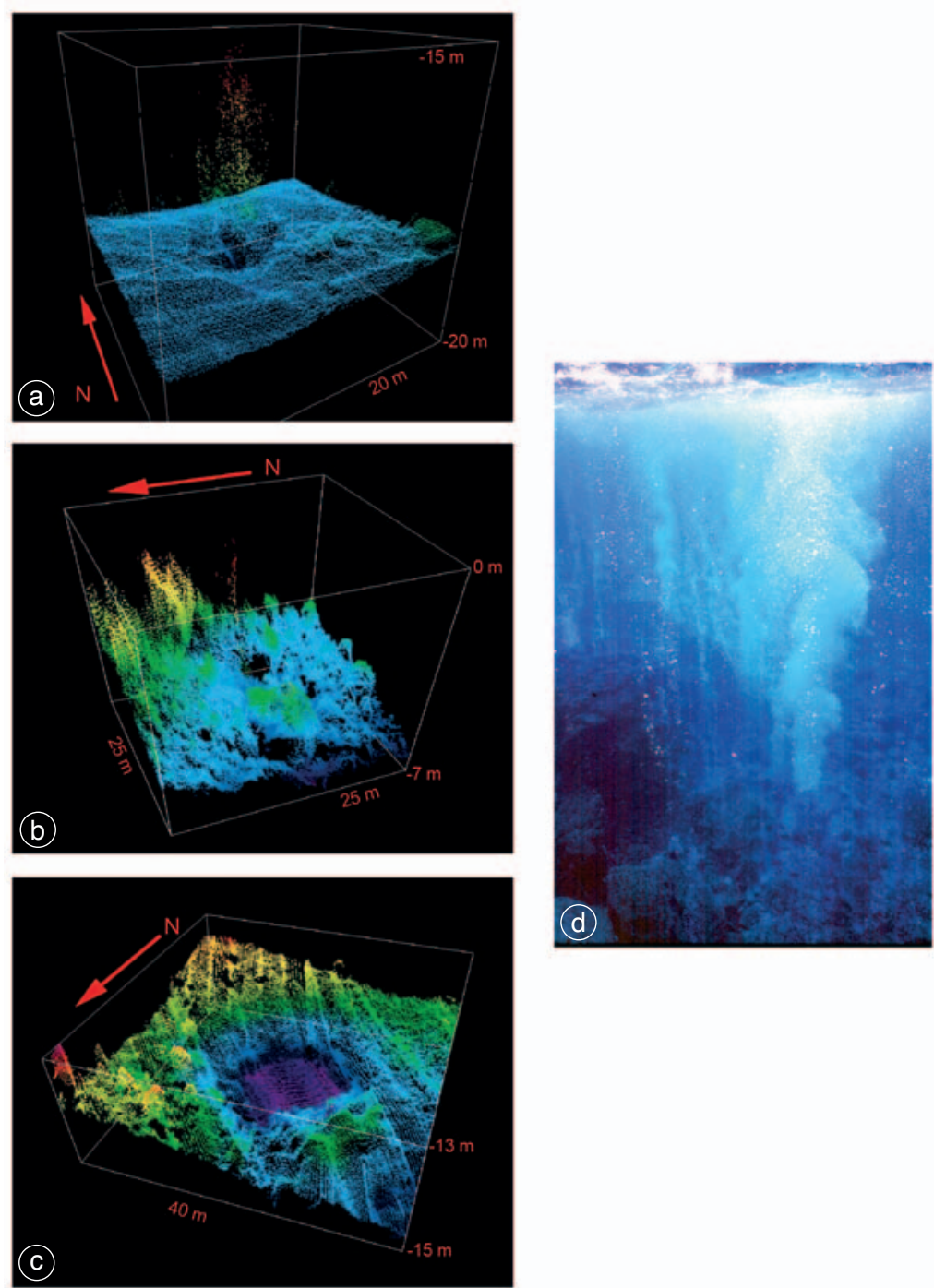

Fig. 6a-d. a-c) Multibeam images of some typical exhalation centres (vertical exaggeration $4 X$ ), showing uprising gas bubbles from the seafloor and the related small size craters produced by the exhalation activity; d) underwater picture of exhalation centres west of Bottaro Island. Gas bubbles are reaching the sea surface (0A class).

2000), specifically designed to process multibeam data under Windows $\mathrm{NT}^{\circledast}$ and capable to manage images in a mosaic of the seafloor and produce raster and analytical maps. The data processing sequence was as follows:

1. System calibration and multibeam data reprocessing.
2. Data quality check: only $15 \%$ of the data were discarded due to a low signal to noise ratio.

3. Sea level correction using the tide gauge and RTK data (fig. 5a,b).

4. High and medium frequency spike removal, keeping intact the signatures produced by the uprising gas bubbles from the seafloor (fig. 6a-d). 
5. Production of high accuracy Marine Digital Elevation Models (MDEM) (table III).

Through the repeated computations, the signal to noise ratio was greatly improved, allowing a precise discrimination of the significant signal and the subsequent identification and location of EC (table IV).

A total of $606 \mathrm{EC}$ were detected (Appendix) and classified by intensity and significance level (fig. 7b). The latter criteria were expressed by the number of soundings that identified each EC from multiple overlapping swaths (0-1-2 levels of table IV) and from their height above the seafloor (A-B-C levels of table IV).

The exhalation centres were further divided into three classes (table IV):

A) High activity centres, with bubbles columns interesting the entire water column up to the sea surface (figs. 6d and 8).

B) Medium activity centres, with bubble columns extending for 3 to $4 \mathrm{~m}$ from the bottom but not reaching the sea surface (fig. 8).

C) Moderate activity centres, with bubble columns extending up to $2 \mathrm{~m}$ from the ground floor, not reaching the sea surface (fig. 6a).
The classified EC were mapped over the MDEM, allowing a view of the active exhalation centres for the whole area during the time span 2002-2003 (fig. 7a), and at December 2002 , during the maximum intensity of the crisis (fig. 7b). Bathymetric surveys were partially repeated during July and December 2003 (fig. 4), focusing on the most active area around Lisca Bianca, Bottaro and EC-1 (fig. 7b).

To produce the MDEM at $0.5 \mathrm{~m}$ average pixel size, of 9 million of 3D punctual data in the UTM33-WGS84 coordinate system were used.

The MDEM for each survey data set (December 2002, July and December 2003), was analysed to reduce any positioning offset or error. The difference grids display pixels whose values are the difference of depth at two survey epochs. The residuals between the three MDEMs were estimated, as reported in table III. By the average standard deviations and excluding values $>1 \mathrm{~m}$, supposed to be related to the active exhalation centres, the statistical difference between the surveys for all the investigated area was estimated within $14 \mathrm{~cm}$.

Table III. Accuracy of the MDEMs.

\begin{tabular}{ccc}
\hline \hline $\begin{array}{c}\text { Survey epoch } \\
\text { (month/year) }\end{array}$ & $\begin{array}{c}\text { Average of the residuals } \\
\text { between grids }(\mathrm{m})\end{array}$ & $\begin{array}{c}\text { Average standard deviation } \\
\text { between grids }(\mathrm{m})\end{array}$ \\
\hline $12 / 03-12 / 02$ & +0.02 & 0.14 \\
$07 / 03-12 / 02$ & +0.10 & 0.13 \\
$12 / 03-07 / 03$ & -0.09 & 0.11 \\
\hline
\end{tabular}

Table IV. Classification of the exhalation centres.

\begin{tabular}{|c|c|c|c|}
\hline Detection level & $\begin{array}{l}\text { Based on the number } \\
\text { of lines which detected } \\
\text { the exhalation centre }\end{array}$ & $\begin{array}{l}\text { Based on the height } \\
\text { extension of the gas column }\end{array}$ & $\begin{array}{l}\text { Based on the quality } \\
\text { of the detection }\end{array}$ \\
\hline High & 0 (>3 lines) & $\begin{array}{l}\text { A (all water column, } \\
\text { from seafloor to sea surface) }\end{array}$ & $\begin{array}{c}\text { 0A (high) } \\
\text { 0B (medium) } \\
\text { 0C (low) }\end{array}$ \\
\hline Medium & $1(2 \div 3$ lines $)$ & B (4 $\mathrm{m}$ height from the seafloor) & $\begin{array}{c}\text { 1A (high) } \\
\text { 1B (medium) } \\
1 \mathrm{C} \text { (low) }\end{array}$ \\
\hline Low & $2(1 \div 2$ lines $)$ & $\mathrm{C}$ ( $2 \mathrm{~m}$ height from seafloor) & $\begin{array}{c}\text { 2A (high) } \\
\text { 2B (medium) } \\
\text { 2C (low) }\end{array}$ \\
\hline
\end{tabular}




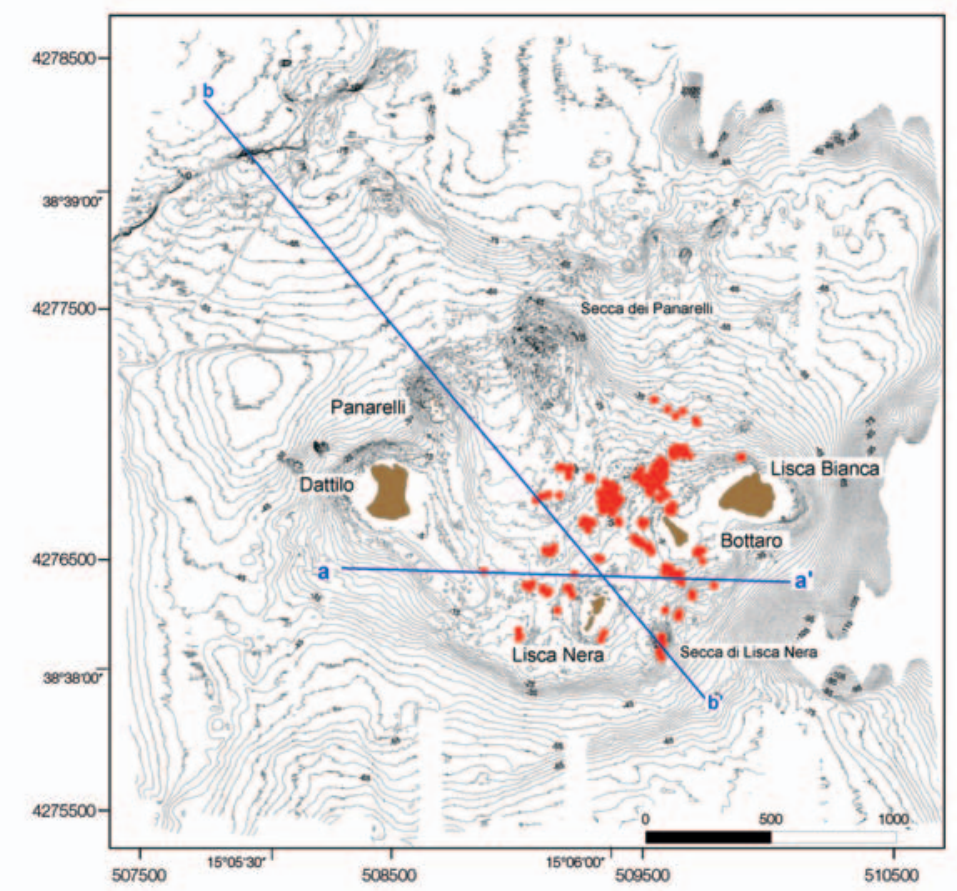

(a)

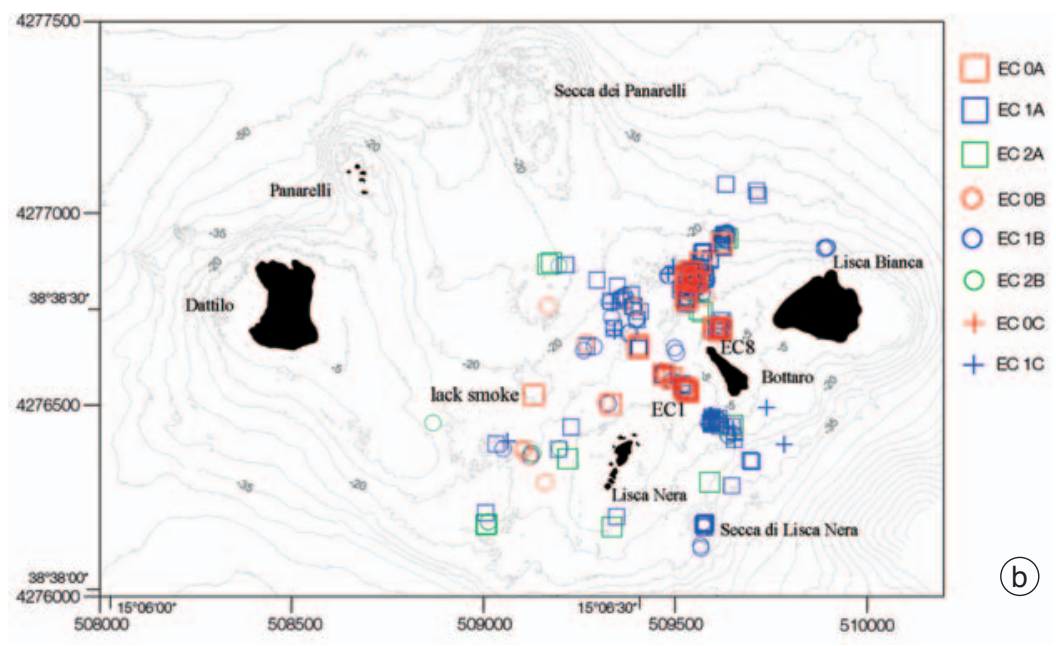

Fig. 7a,b. a) Bathymetry of Panarea Archipelago at $2.0 \mathrm{~m}$ countour level. The red dots are the A and B classes of exhalation centres, respectively, detected in the time span December 2002-December 2003. Blue lines are the cross sections aa' and b b'; b) location of the main exhalation centres active during December 2002, based on their classification (Appendix). In the map are shown the EC-1 (latitude $383818.8 \mathrm{~N}$; longitude 150634.0E, depth $13.3 \mathrm{~m}$ ), EC-8 (latitude 383819.9N, longitude 150637.1E, depth $8.7 \mathrm{~m}$ ), which were the largest exhalation centres and the EC named black smoke (latitude $383815.1 \mathrm{~N}$, longitude 150617.4E, depth $20.8 \mathrm{~m}$ ). The latter is a $175 \mathrm{~m}$ wide and $5 \mathrm{~m}$ deep subcircular depression, interested by moderate dark exhalation, surrounded by lava outcrops that show deposition of alunite, sulfur and sulfates. 


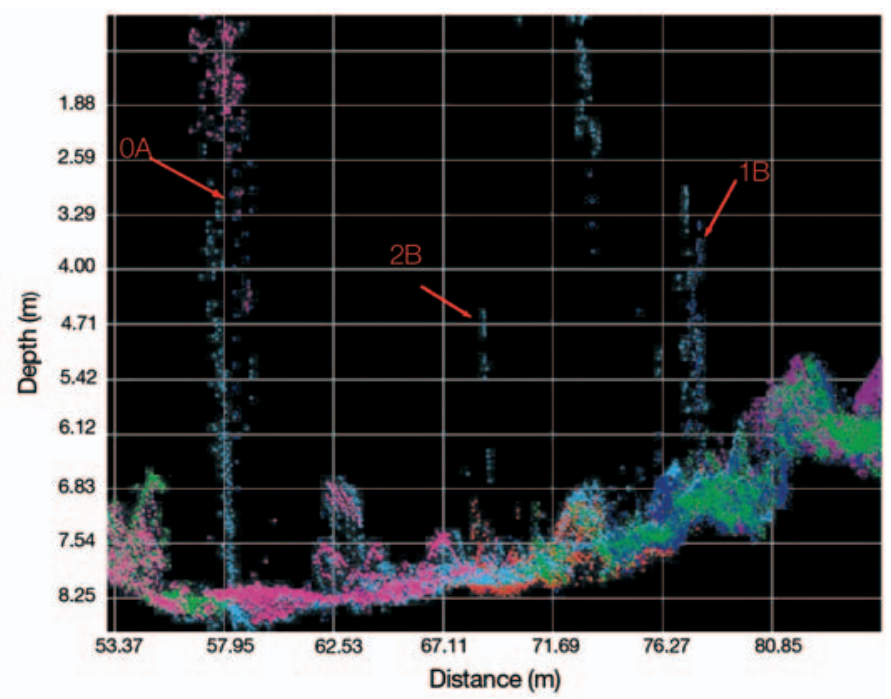

Fig. 8. Classification of the exhalation centres based on their intensity, as detected by the multibeam sensor. See also table III.
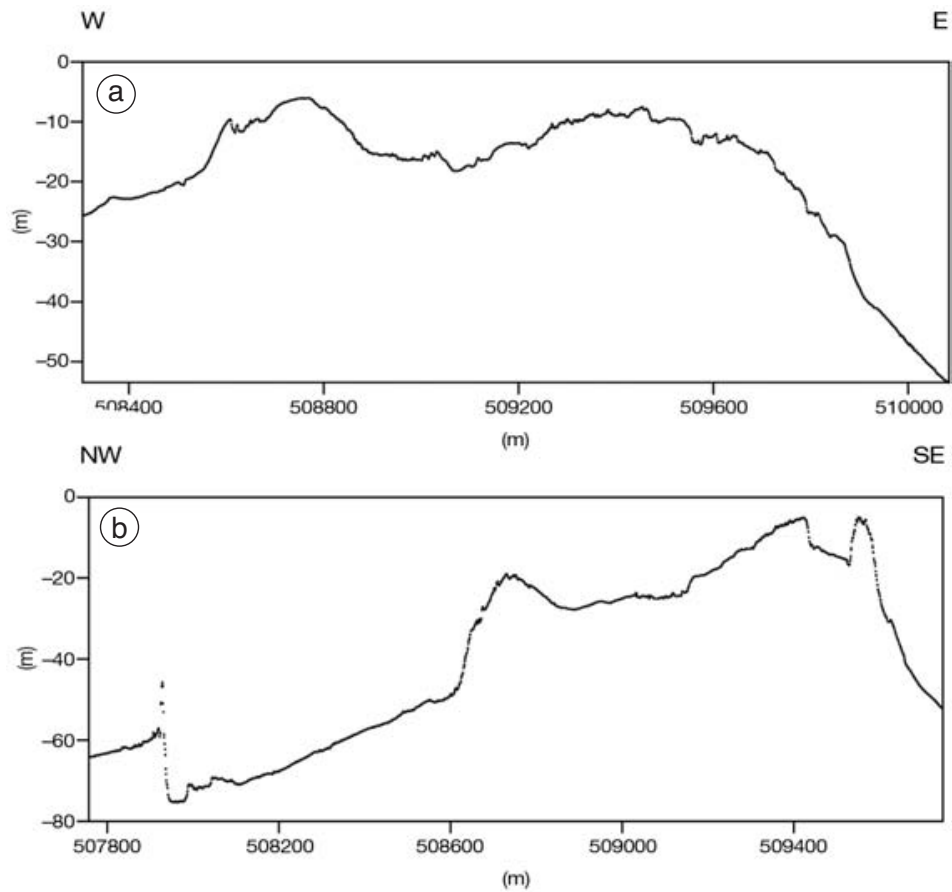

Fig. 9a,b. Cross sections of the investigated area: aa', bb', running a) W-E and b) NW-SE, respectively. It is remarkable the $20 \mathrm{~m}$ height vertical slope in cross section aa', that could be related with a tectonic structure running SW-NE (labelled with A in fig.10a). 
Once the offsets were analysed and applied, the final MDEMs were produced and made available for the morphostructural analysis, including the Exhalation Center (EC) detection, production of contour maps at 1:2500 scale (fig. 7a,b), cross sections (fig. 9a,b) and shaded relief (fig. 10a,b), which show the roughness and complexity of this sector of the Panarea volcano surface.
Applying this analysis to a limited area including the EC-1, a crater about $40 \mathrm{~m}$ long, 15 $\mathrm{m}$ wide and $9 \mathrm{~m}$ deep (fig. 11), which was the largest activated on December 2002, the morphological differences during time were evidenced. Figure 12 shows the results obtained by comparing the December 2002-December 2003 data: starting from a reference surface which fits the average surface of the seafloor around

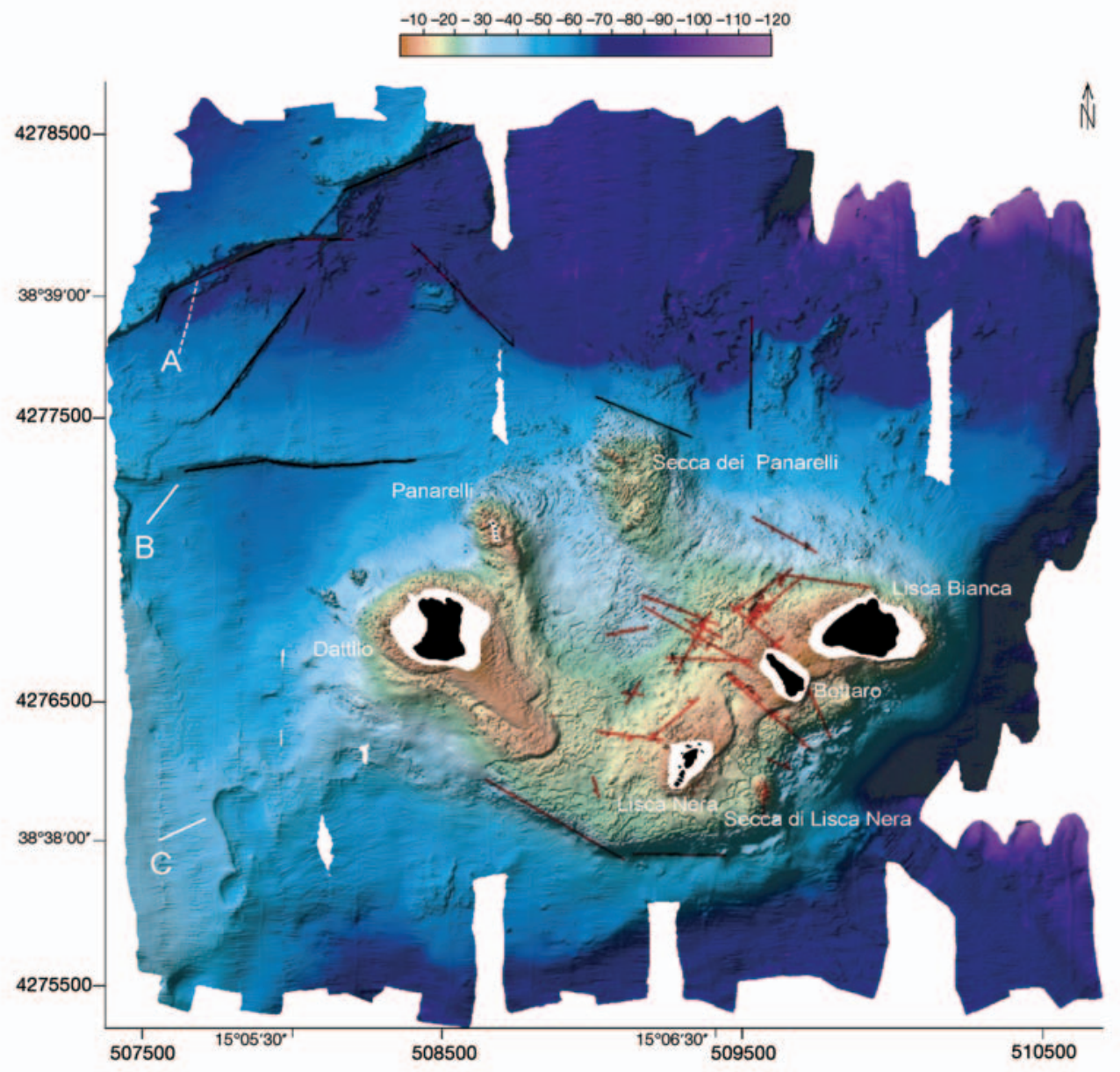

Fig. 10a. Marine Digital Elevation Model (MDEM) showing the morphobathymetry of the area. Scale colour shows depths ranging between 0 and $-60 \mathrm{~m}$. Exhalation centres (red dots) and main lineaments (red lines) revealed by the exhalation centres distribution are reported in the map. The exhalation area is located at the top of the stratovolcano. A and B, are two areas that displays relevant tectonic features; $\mathrm{C}$, is likely to be a past exhalation centre. 


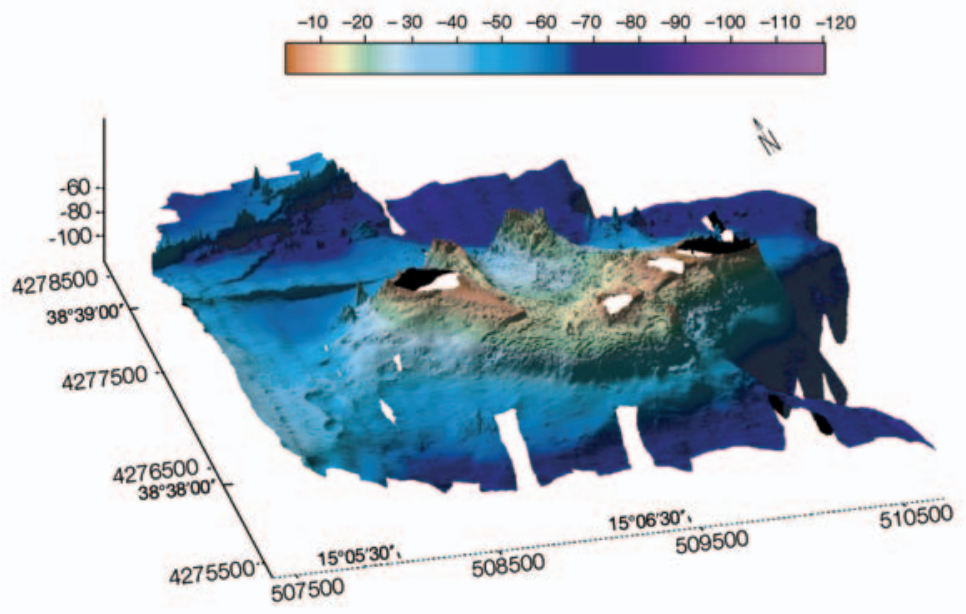

Fig. 10b. Three dimensional view of the area (vertical exaggeration $=2$ ).

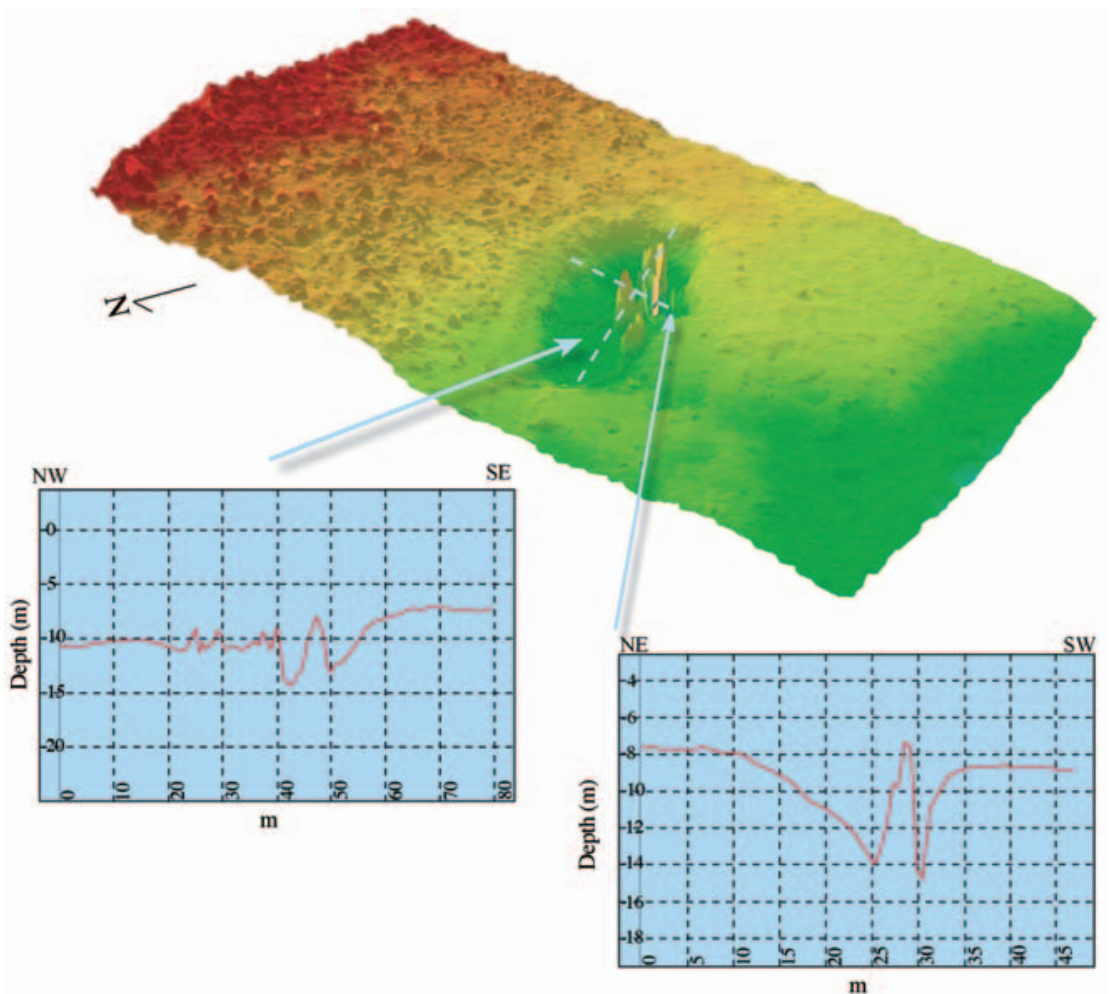

Fig. 11. Digital Terrain Model of the EC-1. The cross section profiles obtained by multibeam data displayed a crater about $40 \mathrm{~m}$ long, $15 \mathrm{~m}$ wide and $9 \mathrm{~m}$ deep. The spikes located in the deepest part of the crater are the uprising gas bubbles. 
the EC-1, we tentatively estimated that the explosive opening of the crater produced an extraction at $3852 \mathrm{~m}^{3}$ of rock during the maximum of the crisis. One year after its opening, the crater was partially filled with approximately $221 \mathrm{~m}^{3}$ of debris due to rock falls of the inner flank of the crater the upwelling gas and water flows.

\section{Discussion and conclusions}

The high resolution multibeam technique provided the first 3D detailed bathymetric map of the seafloor at $0.5 \mathrm{~m}$ average pixel resolution and the location and distribution of the exhalation centres, during the crisis that has affected the Panarea area since November 2002 (fig. $10 \mathrm{a}, \mathrm{b})$. These data are useful to improve and support the geological, volcanological, geochemical, geophysical research and monitoring of this still poorly known volcanic area. Moreover, they represent the first accurate record of the last submarine exhalation crisis which occurred at Panarea.

The MDEM (fig. 10a,b) shows that the area of Panarea Archipelago represents a positive geomorphic feature which is defined by the the coalescence of individual volcanic edifices. This is an asymmetric structure sloping at high angle in its southeastern flank while the others flanks display smoother slopes. The area within the Islets is characterised by a shallow seafloor platform, bewteen 0 and $-30 \mathrm{~m}$, gently slooping to NW between Panarelli and Secca dei Panarelli (fig. 10a,b). Lisca Bianca, Bottaro and Lisca Nera islets are NE-trending coalescent structures. The Dattilo structure shows an elongated tongue-like marine abrasion platform, SE trending, for $0.8 \mathrm{~km}$ at depths between -5 and $-8 \mathrm{~m}$.

The area within the Islets is dotted by hundreds of circular or horseshoe-shaped depressions up to several metres deep and wide, largely distributed especially surrounding Dattilo, Lisca Nera and Bottaro. The high frequency relief of coarse textured morphology, at metre to decimetre size pinnacles and troughs, is well developed between Lisca Bianca, Bottaro and Secca dei Panarelli. In the area between
Panarelli and Secca dei Panarelli the map reveals large lava flow surfaces, smooth and lobed.

The deepest sector dislays evident morphological structures such as those located in the northwest area, NE- NNE- NNW- and E-trending lineaments (fig. 10a: A,B). The southwest sector displays a sub-elliptical shape wide depression probably due gravitative movements (C in fig. 10a).

The shaded relief (fig. 10a,b) does not show a caldera-like structure as suggested in Gabianelli et al. (1990) and Caliro et al. (2004).

The high quality of the surveys disclosed 606 exhalation centres (Apppendix), which were classified on the basis of their different size and activity level, as estimated from the interferences on the multibeam sensor. The location of the gas vents, mapped on the bathymetric maps, revealed the existence of preferential EC aligments NE-SW and NW-SE trending (fig. 10a,b) and along which the gas eruption took place. These alignments match those measured from the fractures, the alunite veins and the fossil gas-pipes exposed on the lava of the seafloor and along the Islets' cliffs (Anzidei et al., 2003, 2004a,b; Esposito et al., 2005). Therefore we suggest that the NE-SW and NWSE systems are the main pathways for the upwelling of hydrothermal fluids.

The comparison between the gas bubble alignments and those inferred by morphologycal analysis, suggests that presently the gas path is mainly driven by an active extension along the NE- and NW-trending fracture systems. The trends of the fracture systems are in agreement with the main regional tectonic structures (De Astis et al., 2003).

The maximum number of exhalation centres was located in a limited extended zone, west of Bottaro and Lisca Bianca islets, whereas clusters of minor centres were sparse in the area. The largest and most active exhalation centre EC-1 was located a few tenths of metres south of Bottaro (figs. 7b and 11). The ellipsoidal crater rim spans between $-8 \mathrm{~m}$ and $-15 \mathrm{~m}$. Its main axis, NW-oriented, is $40 \mathrm{~m}$ long and the minor axis is $25 \mathrm{~m}$ long. The hundreds of depression features identified on the seafloor (fig. $10 \mathrm{a}, \mathrm{b})$ can be related to fossil exhalation cen- 


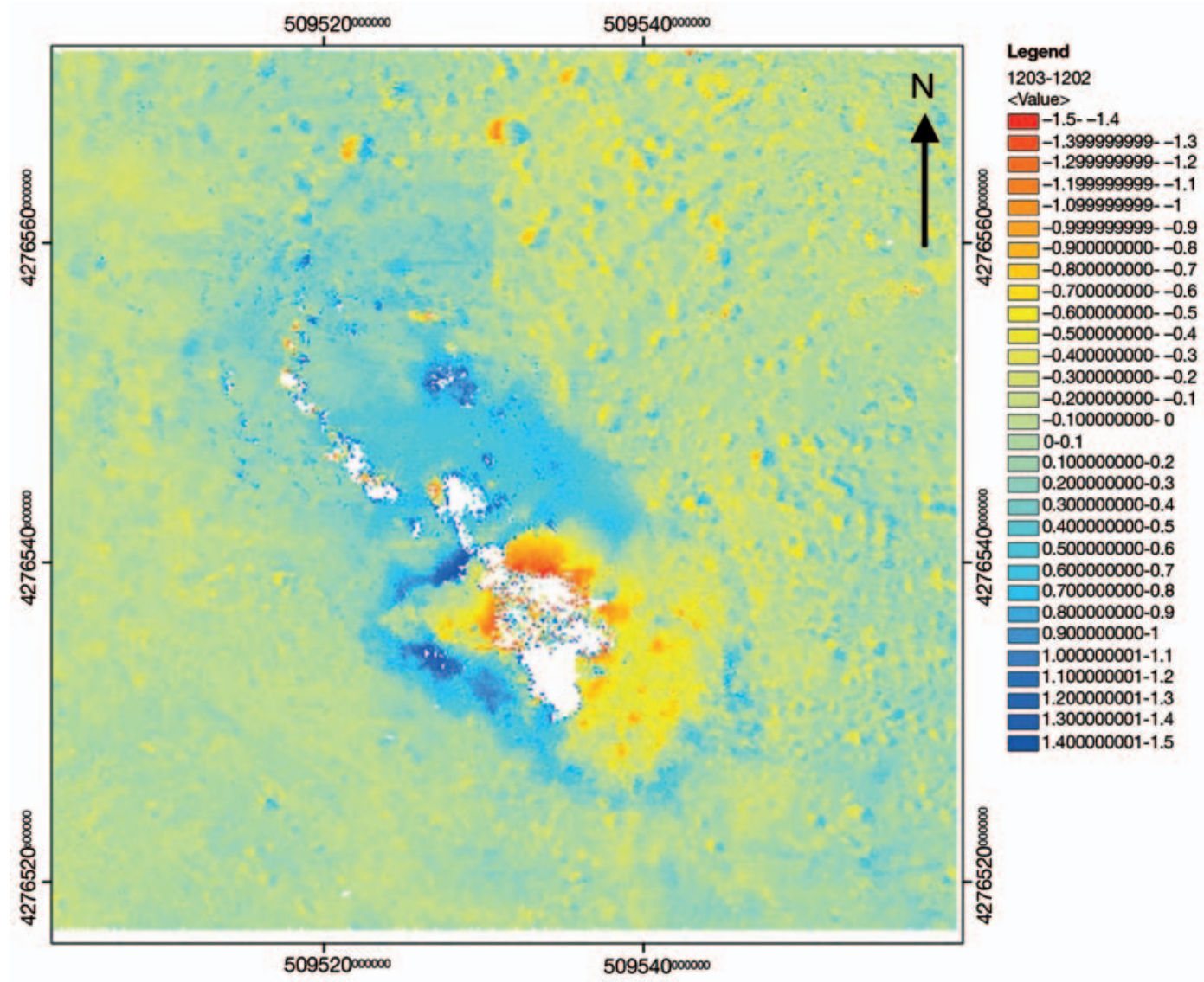

Fig. 12. Topographic changes of the groundfloor at the EC-1, after one year from its opening. The differential MDEM obtained from multibeam data in the time span December 2002-December 2003, estimated $3852 \mathrm{~m}^{3}$ of extracted rock during the gas explosion; $221 \mathrm{~m}^{3}$ were recovered after 12 months, due to a continuous but decreasing gas flux from the seafloor. Positive values are negative groundfloor changes (blue) due to slides inside the crater; negative values (red) are positive groundfloor changes, due to the progressive filling of the bottom of the crater.

tres suggesting that the area has been the site of past episodes of gas eruptions similar to that of November 2002 (Anzidei et al., 2003, 2004 a,b; Esposito et al., 2005).

The differential MDEM obtained from multibeam data in the time span December 2002-December 2003, estimated $3852 \mathrm{~m}^{3}$ of extracted rock during the gas explosion; $221 \mathrm{~m}^{3}$ were recovered after 12 months, due to a continuous but decreasing gas flux from the seafloor (fig. 12). As far as the tectonic and vol- canic interpretations are not the object of this paper, which aims to shows bathymetric survey data and results applied to the submarine part of Panarea volcano, we think that a change in the regional and local strain fields in this area may have produced a reactivation of previous fractures or the opening of new ones, causing a subsequent gas exhalation during the 2002-2003 Panarea crisis, as more extensively described in Caliro et al. (2004), Caracausi et al. (2005) and Esposito et al. (2005). 
Appendix.

Coordinates of the 606 exhalation centres (UTM 33 coordinates). Their depth reported to the mean sea level during surveys, classification and epoch of detection, are also reported.

\begin{tabular}{|c|c|c|c|c|c|c|c|c|c|c|c|}
\hline \multicolumn{6}{|c|}{ EC 0A 12/02 } & \multirow{5}{*}{$\begin{array}{l}39 \\
40 \\
41 \\
42 \\
43 \\
\end{array}$} & \multirow{2}{*}{$\begin{array}{l}150637.10 \\
150637.27\end{array}$} & \multirow{2}{*}{$\begin{array}{l}383819.65 \\
383819.65\end{array}$} & \multirow{2}{*}{$\begin{array}{c}8 \\
8.1\end{array}$} & \multirow{2}{*}{$\begin{array}{l}0 \mathrm{~A} \\
0 \mathrm{~A}\end{array}$} & \multirow{2}{*}{$\begin{array}{l}12 / 02 \\
12 / 02\end{array}$} \\
\hline No. & Long & Lat & Depth & Class & Date & & & & & & \\
\hline 1 & 150634.05 & 383823.87 & 13.6 & $0 \mathrm{~A}$ & $12 / 02$ & & & 383819.72 & 8 & $0 \mathrm{~A}$ & $12 / 02$ \\
\hline 2 & 150634.41 & 383814.31 & 13.2 & $0 \mathrm{~A}$ & $12 / 02$ & & 150626.09 & 383813.30 & 12.5 & $0 \mathrm{~A}$ & $12 / 02$ \\
\hline 3 & 150634.41 & 383814.35 & 13.1 & $0 \mathrm{~A}$ & $12 / 02$ & & 150617.69 & 383814.06 & 22.5 & $0 \mathrm{~A}$ & $12 / 02$ \\
\hline 4 & 150631.68 & 383815.80 & 11.8 & $0 \mathrm{~A}$ & $12 / 02$ & \multicolumn{2}{|c|}{ EC 0B 12/02 } & & & & \\
\hline 5 & 150629.03 & 383818.20 & 12.4 & $0 \mathrm{~A}$ & $12 / 02$ & No. & Long & Lat & Depth & Class & Date \\
\hline 6 & 150629.03 & 383818.17 & 12.5 & $0 \mathrm{~A}$ & $12 / 02$ & & & & 119 & $0 \mathrm{~B}_{2}$ & $12 / 02$ \\
\hline 7 & 150628.99 & 383818.04 & 12.3 & $0 \mathrm{~A}$ & $12 / 02$ & & 150631. & $\begin{array}{l}15 . / 0 \\
15.67\end{array}$ & $\begin{array}{l}11.9 \\
11.7\end{array}$ & OB & $\begin{array}{l}12 / 02 \\
12 / 02\end{array}$ \\
\hline 8 & 150634.32 & 383814.30 & 13 & $0 \mathrm{~A}$ & $12 / 02$ & & 4 & 70 & 11.7 & $0 \mathrm{~B}$ & $2 / 02$ \\
\hline 9 & 150634.12 & 383814.56 & 11.3 & $0 \mathrm{~A}$ & $12 / 02$ & & & & & & 2 \\
\hline 10 & 150634.16 & 383814.52 & 11.2 & $0 \mathrm{~A}$ & $12 / 02$ & & 0621 & 815.76 & 11.8 & OB & 102 \\
\hline 11 & 150634.09 & 383814.51 & 11.3 & $0 \mathrm{~A}$ & $12 / 02$ & 4 & 150631.80 & 383815.76 & 11.9 & B & $2 / 02$ \\
\hline 12 & 150634.20 & 383814.48 & 11.3 & $0 \mathrm{~A}$ & $12 / 02$ & 49 & 150631.89 & 383815.76 & 12.2 & OB & $12 / 02$ \\
\hline 13 & 150634.20 & 383814.43 & 11.3 & $0 \mathrm{~A}$ & $12 / 02$ & 50 & 150631.89 & 383815.83 & 12.2 & OB & $12 / 02$ \\
\hline 14 & 150633.83 & 383814.66 & 11.4 & $0 \mathrm{~A}$ & $12 / 02$ & 51 & 150631.89 & 383815.83 & 12 & OB & $12 / 02$ \\
\hline 15 & 150632.67 & 383815.37 & 11.2 & $0 \mathrm{~A}$ & $12 / 02$ & 52 & 150631.72 & 383815.83 & 12.1 & OB & $12 / 02$ \\
\hline 16 & 150632.69 & 383815.44 & 11.5 & $0 \mathrm{~A}$ & $12 / 02$ & 53 & 150631.55 & 383816.02 & 12.2 & OB & $12 / 02$ \\
\hline 17 & 150634.01 & 383823.68 & 13.7 & $0 \mathrm{~A}$ & $12 / 02$ & 54 & 150631.72 & 383815.86 & 12.1 & OB & $12 / 02$ \\
\hline 18 & 150634.05 & 383823.84 & 12.7 & $0 \mathrm{~A}$ & $12 / 02$ & 55 & 150633.93 & 383814.60 & 11.3 & OB & $12 / 02$ \\
\hline 19 & 150634.88 & 383823.74 & 16 & $0 \mathrm{~A}$ & $12 / 02$ & 56 & 150633.77 & 383814.73 & 11.3 & OB & $12 / 02$ \\
\hline 20 & 150634.09 & 383823.94 & 13 & $0 \mathrm{~A}$ & $12 / 02$ & 57 & 150623.37 & 383818.43 & 21.5 & OB & $12 / 02$ \\
\hline 21 & 150634.13 & 383824.00 & 12.6 & $0 \mathrm{~A}$ & $12 / 02$ & 58 & 150628.63 & 383821.44 & 13.2 & OB & $12 / 02$ \\
\hline 22 & 150635.17 & 383824.03 & 16.2 & $0 \mathrm{~A}$ & $12 / 02$ & 59 & 150634.54 & 383823.78 & 17 & OB & $12 / 02$ \\
\hline 23 & 150634.26 & 383824.16 & 11.9 & $0 \mathrm{~A}$ & $12 / 02$ & 60 & 150635.04 & 383823.94 & 16.5 & 0B & $12 / 02$ \\
\hline 24 & 150634.88 & 383824.39 & 15.1 & $0 \mathrm{~A}$ & $12 / 0$ & 61 & 150634.09 & 383822.02 & 10.8 & OB & $12 / 02$ \\
\hline 25 & 150634.63 & 383824.49 & 14.7 & $0 \mathrm{~A}$ & & 62 & 150634.54 & 383822.22 & 10.9 & OB & $12 / 02$ \\
\hline 26 & 150635.70 & 383825.14 & 17.5 & $0 \mathrm{~A}$ & 0 & 63 & 150636.20 & 383822.28 & 10.3 & OB & $12 / 02$ \\
\hline 27 & 150635.71 & 383825.20 & 17.5 & $0 \mathrm{~A}$ & $12 / 0$ & 64 & 150634.67 & 383823.58 & 16.1 & OB & $12 / 02$ \\
\hline 28 & 150638.02 & 383826.82 & 19.2 & $0 \mathrm{~A}$ & $12 / 0$ & 65 & 150634.59 & 383823.52 & 15.8 & OB & $12 / 02$ \\
\hline 29 & 150638.07 & 383826.85 & 19.2 & $0 \mathrm{~A}$ & & 66 & 150634.17 & 383822.96 & 12.5 & OB & $12 / 02$ \\
\hline 30 & 150634.09 & 383821.99 & 10.8 & $0 \mathrm{~A}$ & 102 & 67 & 150637.97 & 383819.55 & 6.3 & OB & $12 / 02$ \\
\hline 31 & 150634.21 & 383822.06 & 10 & & & 68 & 150638.01 & 383819.62 & 6.7 & OB & $12 / 02$ \\
\hline 32 & 1500 & & 109 & & 02 & 69 & 150637.64 & 383819.62 & 7.7 & OB & $12 / 02$ \\
\hline 33 & 150634.96 & & & & 10 & 70 & 150637.56 & 383819.75 & 8.2 & 0B & $12 / 02$ \\
\hline 34 & 1506 & 38 & $10+3$ & 0 & $12 / 02$ & 71 & 150619.28 & 383821.52 & 25.4 & 0B & $12 / 02$ \\
\hline 35 & & & & & $12 / 02$ & 72 & 15062 & 383813.40 & 12.4 & OB & $12 / 02$ \\
\hline 36 & & & & & 102 & 15 & $15061 / .15$ & $3838,08.87$ & 13.4 & $0 \mathrm{~B}$ & $12 / 02$ \\
\hline 37 & & & 12. & & 10 & 74 & 150616.49 & 383809.35 & 14 & OB & $12 / 02$ \\
\hline 38 & $\begin{array}{l}15003 \\
15063\end{array}$ & 5838 & 0.1 & 0 & $12 / 02$ & 75 & 150616.57 & 383809.55 & 13.9 & OB & $12 / 02$ \\
\hline & & & & & & 10 & & & & UB & 2 \\
\hline
\end{tabular}




\begin{tabular}{|c|c|c|c|c|c|c|c|c|c|c|c|}
\hline \multicolumn{6}{|c|}{ EC 0C 12/02 } & \multirow{2}{*}{$\begin{array}{l}118 \\
119\end{array}$} & \multirow{2}{*}{$\begin{array}{l}150623.41 \\
150626.73\end{array}$} & \multirow{2}{*}{$\begin{array}{l}383818.14 \\
383823.20\end{array}$} & \multirow{2}{*}{$\begin{array}{l}20.9 \\
18.9\end{array}$} & \multirow{2}{*}{$\begin{array}{l}1 \mathrm{~A} \\
1 \mathrm{~A}\end{array}$} & \multirow{2}{*}{$\begin{array}{l}12 / 02 \\
12 / 02\end{array}$} \\
\hline No. & Long & Lat & Depth & Class & Date & & & & & & \\
\hline & & & & & & 120 & 150627.47 & 383822.00 & 16.7 & $1 \mathrm{~A}$ & $12 / 02$ \\
\hline 77 & 150632.71 & 383815.54 & 11.6 & $0 \mathrm{C}$ & $12 / 02$ & 121 & 150626.02 & 383821.93 & 17 & $1 \mathrm{~A}$ & $12 / 02$ \\
\hline 78 & 150634.88 & 383823.81 & 16.4 & $0 \mathrm{C}$ & $12 / 02$ & 122 & 150626.35 & 383819.63 & 17.2 & $1 \mathrm{~A}$ & $12 / 02$ \\
\hline 79 & 150637.23 & 383819.75 & 8 & $0 \mathrm{C}$ & $12 / 02$ & 123 & 150633.55 & 383822.87 & 12.2 & $1 \mathrm{~A}$ & $12 / 02$ \\
\hline \multicolumn{2}{|c|}{ EC 1A 12/02 } & & & & & 124 & 150633.55 & 383822.87 & 12.2 & $1 \mathrm{~A}$ & $12 / 02$ \\
\hline No. & Long & Lat & Depth & Class & Date & 125 & 150634.01 & 383823.06 & 12.5 & $1 \mathrm{~A}$ & $12 / 02$ \\
\hline & & & & & & 126 & 150633.76 & 383823.29 & 12.9 & $1 \mathrm{~A}$ & $12 / 02$ \\
\hline 80 & 150639.03 & 383806.35 & 28.8 & $1 \mathrm{~A}$ & $12 / 02$ & 127 & 150628.21 & 383822.48 & 15.8 & $1 \mathrm{~A}$ & $12 / 02$ \\
\hline 81 & 150641.02 & 383808.49 & 27.5 & $1 \mathrm{~A}$ & $12 / 02$ & 128 & 150628.50 & 383821.51 & 13.5 & $1 \mathrm{~A}$ & $12 / 02$ \\
\hline 82 & 150639.03 & 383806.35 & 29 & $1 \mathrm{~A}$ & $12 / 02$ & 129 & 150628.38 & 383821.45 & 13.7 & $1 \mathrm{~A}$ & $12 / 02$ \\
\hline 83 & 150641.18 & 383808.39 & 27.6 & $1 \mathrm{~A}$ & $12 / 02$ & 130 & 150629.20 & 383821.05 & 13.4 & $1 \mathrm{~A}$ & $12 / 02$ \\
\hline 84 & 150641.22 & 383808.39 & 27.7 & $1 \mathrm{~A}$ & $12 / 02$ & 131 & 150628.87 & 383820.37 & 13.9 & $1 \mathrm{~A}$ & $12 / 02$ \\
\hline 85 & 150639.32 & 383810.27 & 15 & $1 \mathrm{~A}$ & $12 / 02$ & 132 & 150624.53 & 383823.72 & 21.1 & $1 \mathrm{~A}$ & $12 / 02$ \\
\hline 86 & 150636.93 & 383812.19 & 8 & $1 \mathrm{~A}$ & $12 / 02$ & 133 & 150636.20 & 383823.77 & 13.2 & $1 \mathrm{~A}$ & $12 / 02$ \\
\hline 87 & 150636.88 & 383812.03 & 10.2 & $1 \mathrm{~A}$ & $12 / 02$ & 134 & 150636.16 & 383823.77 & 13.8 & $1 \mathrm{~A}$ & $12 / 02$ \\
\hline 88 & 150636.88 & 383811.93 & 10.7 & $1 \mathrm{~A}$ & $12 / 02$ & 135 & 150636.24 & 383823.87 & 13.6 & $1 \mathrm{~A}$ & $12 / 02$ \\
\hline 89 & 150636.97 & 383811.83 & 11.2 & $1 \mathrm{~A}$ & $12 / 02$ & 136 & 150635.83 & 383824.00 & 15 & $1 \mathrm{~A}$ & $12 / 02$ \\
\hline 90 & 150636.97 & 383811.83 & 11.3 & $1 \mathrm{~A}$ & $12 / 02$ & 137 & 150636.28 & 4.03 & 14.2 & $1 \mathrm{~A}$ & $12 / 02$ \\
\hline 91 & 150636.97 & 383811.74 & 11.6 & $1 \mathrm{~A}$ & $12 / 02$ & 138 & 150635.46 & 383824.13 & 15.9 & $1 \mathrm{~A}$ & $12 / 02$ \\
\hline 92 & 150637.71 & 383811.54 & 11.2 & $1 \mathrm{~A}$ & $12 / 02$ & 139 & 150634.96 & 383824.20 & 15.7 & $1 \mathrm{~A}$ & $12 / 02$ \\
\hline 93 & 150636.88 & 383811.64 & 11.6 & $1 \mathrm{~A}$ & $12 / 02$ & 140 & 1506 & 4.23 & 13 & $1 \mathrm{~A}$ & $12 / 02$ \\
\hline 94 & 150636.80 & 383811.57 & 11.7 & $1 \mathrm{~A}$ & $12 / 02$ & 141 & 150635.95 & 383824.33 & 14.5 & $1 \mathrm{~A}$ & $12 / 02$ \\
\hline 95 & 150636.93 & 383811.57 & 11.6 & $1 \mathrm{~A}$ & $12 / 02$ & 142 & 150634.88 & 383824.33 & 16.6 & $1 \mathrm{~A}$ & $12 / 02$ \\
\hline 96 & 15063 & 1.38 & & $1 \mathrm{~A}$ & & 143 & 150636.16 & 383824.33 & 15 & $1 \mathrm{~A}$ & $12 / 02$ \\
\hline 97 & 150639.08 & 383811.38 & 10.4 & $1 \mathrm{~A}$ & $12 / 02$ & 144 & 1506 & 3838 & 15 & $1 \mathrm{~A}$ & $12 / 02$ \\
\hline 98 & 150637.63 & 383812.06 & 10.8 & $1 \mathrm{~A}$ & $12 / 02$ & 145 & 150634.96 & 383824.49 & 16.2 & $1 \mathrm{~A}$ & $12 / 02$ \\
\hline 99 & 150637.30 & 383812.06 & 9.7 & $1 \mathrm{~A}$ & $12 / 02$ & 146 & 150635.46 & 383824.49 & 15.5 & $1 \mathrm{~A}$ & $12 / 02$ \\
\hline 100 & 150636.21 & 383803.14 & 6.9 & $1 \mathrm{~A}$ & $12 / 02$ & 147 & 150634.63 & 383824.52 & 15.2 & $1 \mathrm{~A}$ & $12 / 02$ \\
\hline 101 & 150636.09 & 383803.17 & 6.4 & $1 \mathrm{~A}$ & $12 / 02$ & 148 & 150634.84 & 383824.55 & 15.3 & $1 \mathrm{~A}$ & $12 / 02$ \\
\hline 102 & 150636.17 & 383803.20 & 5.9 & $1 \mathrm{~A}$ & $12 / 02$ & 149 & 150635.71 & 383825.33 & 17.5 & $1 \mathrm{~A}$ & $12 / 02$ \\
\hline 103 & 150636.21 & 383803.14 & 5.4 & $1 \mathrm{~A}$ & $12 / 02$ & 150 & 150 & & 15.6 & $1 \mathrm{~A}$ & $12 / 02$ \\
\hline 104 & 150636.13 & 383803.01 & 6 & $1 \mathrm{~A}$ & $12 / 02$ & 151 & 150636.74 & 383825.53 & 16.5 & $1 \mathrm{~A}$ & $12 / 02$ \\
\hline 105 & 150636.08 & 383803.01 & 6.4 & $1 \mathrm{~A}$ & $12 / 02$ & 152 & 150635.83 & 383825.98 & 15.9 & $1 \mathrm{~A}$ & $12 / 02$ \\
\hline 106 & 150636.08 & 383802.85 & 6.4 & $1 \mathrm{~A}$ & $12 / 02$ & 153 & 150636.08 & 383826.08 & 16.1 & $1 \mathrm{~A}$ & $12 / 02$ \\
\hline 107 & 150636.13 & 383802.82 & 5.9 & $1 \mathrm{~A}$ & $12 / 02$ & 154 & 150635.95 & 383826.14 & 16 & $1 \mathrm{~A}$ & $12 / 02$ \\
\hline 108 & 150635.92 & 383803.04 & 6.4 & $1 \mathrm{~A}$ & $12 / 02$ & 155 & 150638.19 & 383826.50 & 17.8 & $1 \mathrm{~A}$ & $12 / 02$ \\
\hline 109 & 150631.68 & 383815.67 & 11.7 & $1 \mathrm{~A}$ & $12 / 02$ & 156 & 150638.11 & 383826.59 & 18 & $1 \mathrm{~A}$ & $12 / 02$ \\
\hline 110 & 150631.64 & 383815.80 & 11.8 & $1 \mathrm{~A}$ & $12 / 02$ & 157 & 150637.90 & 383826.72 & 18.4 & $1 \mathrm{~A}$ & $12 / 02$ \\
\hline 111 & 150628.99 & 383818.01 & 12.3 & $1 \mathrm{~A}$ & $12 / 02$ & 158 & 150637.82 & 383827.21 & 19.9 & $1 \mathrm{~A}$ & $12 / 02$ \\
\hline 112 & 150629.12 & 383817.97 & 11.9 & $1 \mathrm{~A}$ & $12 / 02$ & 159 & 150638.31 & 383827.60 & 21.4 & $1 \mathrm{~A}$ & $12 / 02$ \\
\hline 113 & 150629.08 & 383817.97 & 11.8 & $1 \mathrm{~A}$ & $12 / 02$ & 160 & 150638.19 & 383827.57 & 21.2 & $1 \mathrm{~A}$ & $12 / 02$ \\
\hline 114 & 150634.36 & 383814.14 & 9.1 & $1 \mathrm{~A}$ & $12 / 02$ & 161 & 150634.17 & 383821.73 & 10.7 & $1 \mathrm{~A}$ & $12 / 02$ \\
\hline 115 & 150633.70 & 383814.78 & 11.3 & $1 \mathrm{~A}$ & $12 / 02$ & 162 & 150634.21 & 383821.83 & 10.7 & $1 \mathrm{~A}$ & $12 / 02$ \\
\hline 116 & 150633.70 & 383814.87 & 11.3 & $1 \mathrm{~A}$ & $12 / 02$ & 163 & 150634.21 & 383821.89 & 10.8 & $1 \mathrm{~A}$ & $12 / 02$ \\
\hline 117 & 150633.71 & 383814.94 & 11.3 & $1 \mathrm{~A}$ & $12 / 02$ & 164 & 150634.21 & 383821.99 & 10.7 & $1 \mathrm{~A}$ & $12 / 02$ \\
\hline
\end{tabular}




\begin{tabular}{|c|c|c|c|c|c|c|c|c|c|c|c|}
\hline 165 & 150634.25 & 383822.19 & 11.1 & $1 \mathrm{~A}$ & $12 / 02$ & 209 & 150627.26 & 383822.32 & 17.6 & 1B & $12 / 02$ \\
\hline 166 & 150634.34 & 383822.22 & 11.3 & $1 \mathrm{~A}$ & $12 / 02$ & 210 & 150627.01 & 383822.22 & 17.6 & 1B & $12 / 02$ \\
\hline 167 & 150634.38 & 383822.35 & 11.4 & $1 \mathrm{~A}$ & $12 / 02$ & 211 & 150627.18 & 383822.13 & 17.6 & $1 \mathrm{~B}$ & $12 / 02$ \\
\hline 168 & 150634.30 & 383822.90 & 12.6 & $1 \mathrm{~A}$ & $12 / 02$ & 212 & 150625.86 & 383821.80 & 17.1 & 1B & $12 / 02$ \\
\hline 169 & 150634.42 & 383822.83 & 12.7 & $1 \mathrm{~A}$ & $12 / 02$ & 213 & 150626.10 & 383820.57 & 16.1 & 1B & $12 / 02$ \\
\hline 170 & 150634.50 & 383822.80 & 12.6 & $1 \mathrm{~A}$ & $12 / 02$ & 214 & 150626.31 & 383819.66 & 17.6 & 1B & $12 / 02$ \\
\hline 171 & 150634.67 & 383822.80 & 12.5 & $1 \mathrm{~A}$ & $12 / 02$ & 215 & 150628.75 & 383820.44 & 14.1 & 1B & $12 / 02$ \\
\hline 172 & 150635.08 & 383823.19 & 14.3 & $1 \mathrm{~A}$ & $12 / 02$ & 216 & 150628.83 & 383820.37 & 13.7 & $1 \mathrm{~B}$ & $12 / 02$ \\
\hline 173 & 150637.39 & 383819.36 & 7.1 & $1 \mathrm{~A}$ & $12 / 02$ & 217 & 150627.88 & 383819.24 & 14.3 & 1B & $12 / 02$ \\
\hline 174 & 150637.56 & 383819.36 & 7 & $1 \mathrm{~A}$ & $12 / 02$ & 218 & 150 & 383 & 14.4 & 1B & $12 / 02$ \\
\hline 175 & 150637.89 & 383819.36 & 4.4 & $1 \mathrm{~A}$ & $12 / 02$ & 219 & 150 & 383 & 14.3 & 1B & $12 / 02$ \\
\hline 176 & 150637.68 & 383819.39 & 7.5 & $1 \mathrm{~A}$ & $12 / 02$ & 220 & 150632.15 & 383824.10 & 14.3 & $1 \mathrm{~B}$ & $12 / 02$ \\
\hline 177 & 150637.43 & 383819.81 & 8 & $1 \mathrm{~A}$ & $12 / 02$ & 221 & 150636.41 & 383823.71 & 12.7 & 1B & $12 / 02$ \\
\hline 178 & 150637.81 & 383820.27 & 7.9 & $1 \mathrm{~A}$ & $12 / 02$ & 222 & 150635.54 & 383823.74 & 16.3 & 1B & $12 / 02$ \\
\hline 179 & 150638.06 & 383820.27 & 7.1 & $1 \mathrm{~A}$ & $12 / 02$ & 223 & 150635.17 & 383824.94 & 16.1 & 1B & $12 / 02$ \\
\hline 180 & 150638.23 & 383827.50 & 21.1 & $1 \mathrm{~A}$ & $12 / 02$ & 224 & 150635.75 & 383824.88 & 16.4 & $1 \mathrm{~B}$ & $12 / 02$ \\
\hline 181 & 150641.96 & 383830.91 & 31.7 & $1 \mathrm{~A}$ & $12 / 02$ & 225 & 150 & 383 & 20 & 1B & $12 / 02$ \\
\hline 182 & 150641.92 & 383830.91 & 31.7 & $1 \mathrm{~A}$ & $12 / 02$ & 226 & 150638.19 & 383827.50 & 20.7 & 1B & $12 / 02$ \\
\hline 183 & 150638.43 & 383831.80 & 31 & $1 \mathrm{~A}$ & $12 / 02$ & 227 & 150638.56 & 383827.70 & 21.4 & 1B & $12 / 02$ \\
\hline 184 & 150641.75 & 383831.26 & 30 & $1 \mathrm{~A}$ & $12 / 02$ & 228 & 150638.44 & 383827.70 & 21.7 & 1B & $12 / 02$ \\
\hline 185 & 150621.14 & 383825.02 & 26.3 & $1 \mathrm{~A}$ & $12 / 02$ & 229 & 150634.71 & 383822.57 & 12.2 & 1B & $12 / 02$ \\
\hline 186 & 150621.70 & 383811.33 & 13.7 & $1 \mathrm{~A}$ & $12 / 02$ & 230 & 150635.87 & 383822.61 & 10.3 & 1B & $12 / 02$ \\
\hline 187 & 150613.64 & 383809.91 & 14.8 & $1 \mathrm{~A}$ & $12 / 02$ & 231 & 150636.03 & 383823.55 & 14.6 & 1B & $12 / 02$ \\
\hline 188 & 150612.51 & 383804.07 & 19.1 & $1 \mathrm{~A}$ & $12 / 02$ & 232 & 150635.50 & 383823.22 & 14.2 & $1 \mathrm{~B}$ & $12 / 02$ \\
\hline 189 & 150626.61 & 383803.73 & 8.1 & $1 \mathrm{~A}$ & $12 / 02$ & 233 & 150637.48 & 383819.98 & 8.5 & 1B & $12 / 02$ \\
\hline 190 & 150620.38 & 383809.45 & 12.8 & $1 \mathrm{~A}$ & $12 / 02$ & 234 & 150638.40 & 383827.05 & 20 & 1B & $12 / 02$ \\
\hline \multicolumn{2}{|c|}{ EC $1 B \quad 12 / 02$} & & & & & & 150638.60 & 383827.73 & 21.9 & 1B & $12 / 02$ \\
\hline \multirow[t]{2}{*}{ No. } & & $\mathrm{La}$ & ep & Ta & Oat & 236 & 150649.07 & 383826.32 & 15.2 & 1B & $12 / 02$ \\
\hline & & & & & & 2 & 150649.07 & 383826.45 & 15.3 & 1B & $12 / 02$ \\
\hline 191 & 150637.55 & 383812.00 & 11 & $1 \mathrm{~B}$ & $12 / 02$ & 238 & 150649.40 & 383826.45 & 15.4 & 1B & $12 / 02$ \\
\hline 192 & 150637.59 & 383811.90 & 11.2 & $1 \mathrm{~B}$ & $12 / 02$ & 239 & 150649.28 & 383826.49 & 15.2 & $1 \mathrm{~B}$ & $12 / 02$ \\
\hline 193 & 150637.13 & 383811.90 & 11.3 & 1B & $12 / 02$ & 240 & 150625.72 & 383813.30 & 12.2 & $1 \mathrm{~B}$ & $12 / 02$ \\
\hline 194 & 150636.84 & 383811.83 & 11.3 & 1B & $12 / 02$ & 241 & 150614.38 & 383809.49 & 14.7 & 1B & $12 / 02$ \\
\hline 195 & 150636.55 & 383811.64 & 11.8 & 1B & $12 / 02$ & 242 & 150617.36 & 383808.87 & 13.3 & 1B & $12 / 02$ \\
\hline
\end{tabular}

$\begin{array}{llllll}196 & 150636.76 & 383811.57 & 11.2 & 1 \mathrm{~B} & 12 / 02\end{array}$

$\begin{array}{llllll}197 & 150638.62 & 383810.63 & 12.7 & 1 \mathrm{~B} & 12 / 02\end{array}$

$\begin{array}{llllll}198 & 150635.71 & 383801.03 & 19.7 & 1 \mathrm{~B} & 12 / 02\end{array}$

$\begin{array}{llllll}199 & 150635.67 & 383801.26 & 18.4 & 1 \mathrm{~B} & 12 / 02\end{array}$

$\begin{array}{llllll}200 & 150636.00 & 383802.85 & 6.5 & \text { 1B } & 12 / 02\end{array}$

$\begin{array}{llllll}201 & 150635.96 & 383803.24 & 6.5 & 1 \mathrm{~B} & 12 / 02\end{array}$

$\begin{array}{llllll}202 & 150633.70 & 383814.89 & 11.4 & 1 \mathrm{~B} & 12 / 02\end{array}$

$\begin{array}{llllll}203 & 150632.63 & 383815.24 & 11.1 & 1 \mathrm{~B} & 12 / 02\end{array}$

$\begin{array}{llllll}204 & 150632.88 & 383818.03 & 11.4 & 1 \mathrm{~B} & 12 / 02\end{array}$

$\begin{array}{llllll}205 & 150633.09 & 383817.61 & 8.1 & 1 \mathrm{~B} & 12 / 02\end{array}$

$\begin{array}{llllll}206 & 150624.24 & 383818.14 & 17.6 & 1 \mathrm{~B} & 12 / 02\end{array}$

$\begin{array}{llllll}207 & 150623.08 & 383817.82 & 16.3 & 1 \mathrm{~B} & 12 / 02\end{array}$

$\begin{array}{llllll}208 & 150627.55 & 383822.39 & 17.8 & 1 \mathrm{~B} & 12 / 02\end{array}$

\section{EC 1C 12/02}

No. Long Lat Depth Class Date

$\begin{array}{llllll}243 & 150644.70 & 383809.85 & 26.8 & 1 \mathrm{C} & 12 / 02\end{array}$

$\begin{array}{llllll}244 & 150639.36 & 383810.21 & 15.2 & 1 \mathrm{C} & 12 / 02\end{array}$

$\begin{array}{llllll}245 & 150642.80 & 383812.96 & 12.8 & 1 \mathrm{C} & 12 / 02\end{array}$

$\begin{array}{llllll}246 & 150639.36 & 383810.27 & 14.8 & 1 \mathrm{C} & 12 / 02\end{array}$

$\begin{array}{llllll}247 & 150636.80 & 383812.32 & 7.4 & 1 \mathrm{C} & 12 / 02\end{array}$

$\begin{array}{llllll}248 & 150636.68 & 383812.29 & 7.5 & 1 \mathrm{C} & 12 / 02\end{array}$

$\begin{array}{llllll}249 & 150637.01 & 383812.22 & 7.7 & 1 \mathrm{C} & 12 / 02\end{array}$

$\begin{array}{llllll}250 & 150636.76 & 383812.19 & 8.1 & 1 \mathrm{C} & 12 / 02\end{array}$

$\begin{array}{llllll}251 & 150636.76 & 383812.29 & 7.3 & 1 \mathrm{C} & 12 / 02\end{array}$

$\begin{array}{llllll}252 & 150636.76 & 383812.13 & 8 & 1 \mathrm{C} & 12 / 02\end{array}$ 


\begin{tabular}{cccccc}
\hline 253 & 150636.76 & 383812.00 & 9.3 & $1 \mathrm{C}$ & $12 / 02$ \\
254 & 150637.21 & 383811.74 & 11.5 & $1 \mathrm{C}$ & $12 / 02$ \\
255 & 150636.55 & 383811.54 & 11.8 & $1 \mathrm{C}$ & $12 / 02$ \\
256 & 150639.16 & 383811.18 & 10.9 & $1 \mathrm{C}$ & $12 / 02$ \\
257 & 150638.66 & 383811.38 & 10.5 & $1 \mathrm{C}$ & $12 / 02$ \\
258 & 150626.23 & 383821.74 & 16.1 & $1 \mathrm{C}$ & $12 / 02$ \\
259 & 150626.43 & 383819.47 & 17 & $1 \mathrm{C}$ & $12 / 02$ \\
260 & 150632.73 & 383824.85 & 15 & $1 \mathrm{C}$ & $12 / 02$ \\
261 & 150632.23 & 383824.26 & 14.7 & $1 \mathrm{C}$ & $12 / 02$ \\
262 & 150634.05 & 383823.84 & 13 & $1 \mathrm{C}$ & $12 / 02$ \\
263 & 150637.86 & 383827.24 & 20.2 & $1 \mathrm{C}$ & $12 / 02$ \\
264 & 150614.83 & 383810.13 & 15.5 & $1 \mathrm{C}$ & $12 / 02$
\end{tabular}

\section{EC 2A 12/02}

\begin{tabular}{cccccc} 
No. & Long & Lat & Depth & Class & Date \\
\hline 265 & 150636.67 & 383806.64 & 19.2 & $2 \mathrm{~A}$ & $12 / 02$ \\
266 & 150639.16 & 383811.48 & 9.8 & $2 \mathrm{~A}$ & $12 / 02$ \\
267 & 150635.91 & 383821.02 & 8 & $2 \mathrm{~A}$ & $12 / 02$ \\
268 & 150635.53 & 383821.21 & 8 & $2 \mathrm{~A}$ & $12 / 02$ \\
269 & 150638.65 & 383827.24 & 21 & $2 \mathrm{~A}$ & $12 / 02$ \\
270 & 150638.36 & 383827.24 & 21 & $2 \mathrm{~A}$ & $12 / 02$ \\
271 & 150619.20 & 383825.05 & 26.2 & $2 \mathrm{~A}$ & $12 / 02$ \\
272 & 150619.61 & 383825.22 & 26.1 & $2 \mathrm{~A}$ & $12 / 02$ \\
273 & 150621.37 & 383808.64 & 12 & $2 \mathrm{~A}$ & $12 / 02$ \\
274 & 150621.33 & 383808.64 & 12 & $2 \mathrm{~A}$ & $12 / 02$ \\
275 & 150612.51 & 383803.03 & 19.8 & $2 \mathrm{~A}$ & $12 / 02$ \\
276 & 150612.63 & 383803.13 & 19.8 & $2 \mathrm{~A}$ & $12 / 02$ \\
277 & 150626.12 & 383802.86 & 10.6 & $2 \mathrm{~A}$ & $12 / 02$ \\
\hline
\end{tabular}

\section{EC 2B 12/02}

\begin{tabular}{cccccc} 
No. & Long & Lat & Depth & Class & Date \\
\hline 278 & 150638.74 & 383810.57 & 13 & 2B & $12 / 02$ \\
279 & 150638.56 & 383827.47 & 21.8 & 2B & $12 / 02$ \\
280 & 150620.44 & 383824.92 & 26.2 & 2B & $12 / 02$ \\
281 & 150617.60 & 383809.09 & 13.6 & 2B & $12 / 02$ \\
282 & 150617.36 & 383809.09 & 13.6 & 2B & $12 / 02$ \\
283 & 150612.80 & 383803.32 & 18.7 & 2B & $12 / 02$ \\
284 & 150612.76 & 383803.26 & 18.9 & 2B & $12 / 02$ \\
285 & 150620.50 & 383809.51 & 12.5 & 2B & $12 / 02$ \\
286 & 150606.81 & 383811.70 & 18.2 & 2B & $12 / 02$ \\
\hline
\end{tabular}

\section{EC 0A 07/03}

No. Long Lat Depth Class Date

$\begin{array}{llllll}287 & 150632.63 & 383815.41 & 11.2 & 0 \mathrm{~A} & 07 / 03\end{array}$

$\begin{array}{llllll}288 & 150634.39 & 383814.30 & 13.1 & 0 \mathrm{~A} & 07 / 03\end{array}$

\section{EC 0B 07/03}

No. Long Lat Depth Class Date

$\begin{array}{llllll}289 & 150641.06 & 383808.59 & 27.4 & \text { OB } & 07 / 03\end{array}$

\begin{tabular}{cccccc}
290 & 150641.06 & 383808.46 & 27.4 & 0B & $07 / 03$ \\
291 & 150641.10 & 383808.39 & 27.5 & 0B & $07 / 03$ \\
292 & 150631.68 & 383815.83 & 11.7 & 0B & $07 / 03$ \\
293 & 150631.80 & 383815.80 & 11.8 & 0B & $07 / 03$ \\
294 & 150631.93 & 383815.83 & 11.9 & 0B & $07 / 03$ \\
295 & 150631.68 & 383815.76 & 11.8 & 0B & $07 / 03$ \\
296 & 150631.72 & 383815.70 & 11.7 & 0B & $07 / 03$ \\
297 & 150631.84 & 383815.70 & 11.6 & 0B & $07 / 03$ \\
298 & 150631.84 & 383815.67 & 11.5 & 0B & $07 / 03$ \\
299 & 150632.71 & 383815.54 & 11 & 0B & $07 / 03$ \\
300 & 150632.71 & 383815.50 & 11 & 0B & $07 / 03$ \\
301 & 150632.55 & 383815.47 & 11.5 & 0B & $07 / 03$ \\
302 & 150632.67 & 383815.44 & 11 & 0B & $07 / 03$ \\
303 & 150632.67 & 383815.34 & 11.1 & 0B & $07 / 03$ \\
\hline
\end{tabular}

\section{EC 0C 07/03}

No. Long Lat Depth Class Date

$\begin{array}{llllll}304 & 150641.18 & 383808.39 & 27.4 & \text { 0C } & 07 / 03\end{array}$

\section{EC 1A 07/03}

No. Long Lat Depth Class Date

\begin{tabular}{lccccc}
\hline 305 & 150639.03 & 383806.15 & 30.9 & $1 \mathrm{~A}$ & $07 / 03$ \\
306 & 150638.78 & 383805.96 & 28.1 & $1 \mathrm{~A}$ & $07 / 03$ \\
307 & 150638.90 & 383805.99 & 29.5 & $1 \mathrm{~A}$ & $07 / 03$ \\
308 & 150638.82 & 383805.90 & 29.2 & $1 \mathrm{~A}$ & $07 / 03$ \\
309 & 150638.82 & 383805.83 & 29.1 & $1 \mathrm{~A}$ & $07 / 03$ \\
310 & 150636.08 & 383802.88 & 5.9 & $1 \mathrm{~A}$ & $07 / 03$ \\
311 & 150641.10 & 383808.78 & 27.2 & $1 \mathrm{~A}$ & $07 / 03$ \\
312 & 150636.97 & 383811.80 & 11.5 & $1 \mathrm{~A}$ & $07 / 03$ \\
313 & 150636.84 & 383811.80 & 11.5 & $1 \mathrm{~A}$ & $07 / 03$ \\
314 & 150636.76 & 383811.77 & 11.5 & $1 \mathrm{~A}$ & $07 / 03$ \\
315 & 150636.84 & 383811.80 & 11.4 & $1 \mathrm{~A}$ & $07 / 03$ \\
316 & 150636.84 & 383811.87 & 11.4 & $1 \mathrm{~A}$ & $07 / 03$ \\
317 & 150637.01 & 383811.77 & 11.6 & $1 \mathrm{~A}$ & $07 / 03$ \\
318 & 150636.80 & 383811.77 & 11.6 & $1 \mathrm{~A}$ & $07 / 03$ \\
319 & 150641.77 & 383814.07 & 8.6 & $1 \mathrm{~A}$ & $07 / 03$ \\
320 & 150641.81 & 383814.10 & 9 & $1 \mathrm{~A}$ & $07 / 03$ \\
321 & 150631.68 & 383815.67 & 11.6 & $1 \mathrm{~A}$ & $07 / 03$ \\
322 & 150632.67 & 383815.31 & 11 & $1 \mathrm{~A}$ & $07 / 03$ \\
323 & 150627.92 & 383822.94 & 16.6 & $1 \mathrm{~A}$ & $07 / 03$ \\
324 & 150626.77 & 383823.17 & 18.5 & $1 \mathrm{~A}$ & $07 / 03$ \\
325 & 150626.10 & 383820.51 & 16.3 & $1 \mathrm{~A}$ & $07 / 03$ \\
326 & 150626.10 & 383820.60 & 16.1 & $1 \mathrm{~A}$ & $07 / 03$ \\
327 & 150626.10 & 383820.64 & 16.4 & $1 \mathrm{~A}$ & $07 / 03$ \\
328 & 150623.78 & 383817.72 & 17.1 & $1 \mathrm{~A}$ & $07 / 03$ \\
329 & 150623.57 & 383817.78 & 16.3 & $1 \mathrm{~A}$ & $07 / 03$ \\
330 & 150624.77 & 383818.01 & 17.3 & $1 \mathrm{~A}$ & $07 / 03$ \\
\hline & & & & &
\end{tabular}




\begin{tabular}{|c|c|c|c|c|c|c|c|c|c|c|c|}
\hline 331 & 150624.82 & 383818.01 & 18 & $1 \mathrm{~A}$ & $07 / 03$ & 378 & 150636.66 & 383824.65 & 13.8 & $1 \mathrm{~A}$ & $07 / 03$ \\
\hline 332 & 150624.28 & 383818.14 & 17.4 & $1 \mathrm{~A}$ & $07 / 03$ & 379 & 150635.58 & 383825.20 & 17.4 & $1 \mathrm{~A}$ & $07 / 03$ \\
\hline 333 & 150623.45 & 383818.40 & 21.1 & $1 \mathrm{~A}$ & $07 / 03$ & 380 & 150635.33 & 383825.49 & 16.6 & $1 \mathrm{~A}$ & $07 / 03$ \\
\hline 334 & 150624.58 & 383823.72 & 21.3 & $1 \mathrm{~A}$ & $07 / 03$ & 381 & 150638.23 & 383826.56 & 17.8 & $1 \mathrm{~A}$ & $07 / 03$ \\
\hline 335 & 150624.04 & 383823.72 & 21.8 & $1 \mathrm{~A}$ & 07/03 & 382 & 150638.07 & 383826.85 & 19.2 & $1 \mathrm{~A}$ & $07 / 03$ \\
\hline 336 & 150624.37 & 383823.88 & 22.5 & $1 \mathrm{~A}$ & $07 / 03$ & 383 & 150635.41 & 383823.58 & 15 & $1 \mathrm{~A}$ & $07 / 03$ \\
\hline 337 & 150634.63 & 383823.58 & 16.2 & $1 \mathrm{~A}$ & $07 / 03$ & 384 & 150635.25 & 383823.55 & 15.1 & $1 \mathrm{~A}$ & $07 / 03$ \\
\hline 338 & 150634.63 & 383823.55 & 16 & $1 \mathrm{~A}$ & $07 / 03$ & 385 & 150634.96 & 383823.58 & 15.5 & $1 \mathrm{~A}$ & $07 / 03$ \\
\hline 339 & 150634.21 & 383823.45 & 14.6 & $1 \mathrm{~A}$ & $07 / 03$ & 386 & 150635.21 & 383823.48 & 15.1 & $1 \mathrm{~A}$ & $07 / 03$ \\
\hline 340 & 150633.80 & 383823.32 & 13.2 & $1 \mathrm{~A}$ & 07/03 & 387 & 150638.11 & 383826.89 & 19.1 & $1 \mathrm{~A}$ & $07 / 03$ \\
\hline 341 & 150633.80 & 383823.32 & 13 & $1 \mathrm{~A}$ & 07/03 & 388 & $1506 ?$ & 383827.24 & 20 & $1 \mathrm{~A}$ & $07 / 03$ \\
\hline 342 & 150634.25 & 383823.16 & 13.7 & $1 \mathrm{~A}$ & 07/03 & 398 & 150617.37 & 383821.58 & 25.2 & $1 \mathrm{~A}$ & $07 / 03$ \\
\hline 343 & 150634.21 & 383823.00 & 13.1 & $1 \mathrm{~A}$ & $07 / 03$ & 399 & 150616.34 & 383821.39 & 25 & $1 \mathrm{~A}$ & $07 / 03$ \\
\hline 344 & 150634.38 & 383822.93 & 12.6 & $1 \mathrm{~A}$ & 07/03 & 400 & 150615.43 & 383820.87 & 24 & $1 \mathrm{~A}$ & $07 / 03$ \\
\hline 345 & 150634.38 & 383822.93 & 12.7 & $1 \mathrm{~A}$ & $07 / 03$ & 401 & 1506 & 383824.50 & 13.7 & $1 \mathrm{~A}$ & $07 / 03$ \\
\hline 346 & 150634.83 & 383822.87 & 12.5 & $1 \mathrm{~A}$ & $07 / 03$ & 402 & 150634.93 & 383833.83 & 33.5 & $1 \mathrm{~A}$ & $07 / 03$ \\
\hline 347 & 150634.87 & 383822.83 & 12.4 & $1 \mathrm{~A}$ & $07 / 03$ & 403 & 150634.85 & 383833.90 & 33.6 & $1 \mathrm{~A}$ & $07 / 03$ \\
\hline 348 & 150634.58 & 383822.80 & 12.4 & $1 \mathrm{~A}$ & $07 / 03$ & 404 & 150620.75 & 383809.51 & 12.5 & $1 \mathrm{~A}$ & $07 / 03$ \\
\hline 349 & 150634.67 & 383822.80 & 12.5 & $1 \mathrm{~A}$ & 07/03 & 405 & 150620.71 & 38380 & 12.5 & $1 \mathrm{~A}$ & $07 / 03$ \\
\hline 350 & 150634.58 & 383822.80 & 12.4 & $1 \mathrm{~A}$ & $07 / 03$ & \multicolumn{6}{|c|}{ EC $1 B$ 07/03 } \\
\hline 351 & 150634.25 & 383822.12 & 11.1 & $1 \mathrm{~A}$ & 07/03 & No. & $\begin{array}{l}\text { Long } \\
\text { Los }\end{array}$ & Lat & Depth & Clas & Date \\
\hline 352 & 150634.54 & 383823.68 & 16 & $1 \mathrm{~A}$ & $07 / 03$ & & & & & & \\
\hline 353 & 150634.88 & 383823.71 & 16.1 & $1 \mathrm{~A}$ & 07/03 & 406 & 150638.99 & 383 & 29.6 & 1B & $07 / 03$ \\
\hline 354 & 150634.92 & 383823.77 & 16.2 & $1 \mathrm{~A}$ & 07/03 & 407 & 150638.98 & 383806.09 & 30.4 & 1B & $07 / 03$ \\
\hline 355 & 150634.09 & 383823.87 & 13.7 & $1 \mathrm{~A}$ & $07 / 03$ & 408 & 8.78 & 383806.06 & 26.8 & $1 \mathrm{~B}$ & $07 / 03$ \\
\hline 356 & 150634.09 & 383823.87 & 13.6 & $1 \mathrm{~A}$ & 07/03 & 409 & 1506 & 383806.02 & 29.2 & 1B & $07 / 03$ \\
\hline 357 & 150634.88 & 383823.90 & 16.7 & $1 \mathrm{~A}$ & $07 / 03$ & 410 & 150638.82 & 383805.93 & 28 & 1B & $07 / 03$ \\
\hline 358 & 150634.88 & 383823.94 & 16.8 & $1 \mathrm{~A}$ & $07 / 03$ & 411 & 150638.82 & 383805.93 & 29.2 & 1B & $07 / 03$ \\
\hline 359 & 150634.79 & 383823.97 & 17.2 & $1 \mathrm{~A}$ & $07 / 03$ & 412 & 150638.90 & 383805.80 & 29 & $1 \mathrm{~B}$ & $07 / 03$ \\
\hline 360 & 150634.13 & 383823.97 & 12.9 & $1 \mathrm{~A}$ & 07/03 & 413 & 150636.13 & 383802.85 & 6.2 & 1B & $07 / 03$ \\
\hline 361 & 150634.63 & 383824.42 & 15.4 & $1 \mathrm{~A}$ & 07/03 & 414 & 150636.00 & 383802.82 & 6. & $1 \mathrm{~B}$ & $07 / 03$ \\
\hline 362 & 150634.59 & 383824.42 & 15.4 & $1 \mathrm{~A}$ & 07/03 & 415 & 150636.04 & 383802.36 & 6.2 & $1 \mathrm{~B}$ & $07 / 03$ \\
\hline 363 & 150636.45 & 383823.74 & 12.9 & $1 \mathrm{~A}$ & 07/03 & 416 & 150635.92 & 383802.43 & 6.3 & 1B & $07 / 03$ \\
\hline 364 & 150636.32 & 383823.87 & 13.6 & $1 \mathrm{~A}$ & $07 / 03$ & 417 & 150641.14 & 383808.59 & 27.2 & 1B & $07 / 03$ \\
\hline 365 & 150636.32 & 383823.90 & 13.6 & $1 \mathrm{~A}$ & 07/03 & 418 & 150636.84 & 383811.87 & 11.3 & $1 \mathrm{~B}$ & $07 / 03$ \\
\hline 366 & 150636.32 & 383823.90 & 14.4 & $1 \mathrm{~A}$ & $07 / 03$ & 419 & 150642.10 & 383814.46 & 10.5 & $1 \mathrm{~B}$ & $07 / 03$ \\
\hline 367 & 150636.20 & 383824.00 & 12.5 & $1 \mathrm{~A}$ & 07/03 & 420 & 150642.31 & 383814.07 & 11.3 & $1 \mathrm{~B}$ & $07 / 03$ \\
\hline 368 & 150636.32 & 383824.07 & 14.3 & $1 \mathrm{~A}$ & 07/03 & 421 & 150641.81 & 383814.13 & 8.9 & $1 \mathrm{~B}$ & $07 / 03$ \\
\hline 369 & 150636.32 & 383824.13 & 14.8 & $1 \mathrm{~A}$ & 07/03 & 422 & 150631.72 & 383815.83 & 11.6 & $1 \mathrm{~B}$ & $07 / 03$ \\
\hline 370 & 150636.65 & 383824.16 & 12.7 & $1 \mathrm{~A}$ & $07 / 03$ & 423 & 150631.93 & 383815.83 & 11.9 & $1 \mathrm{~B}$ & $07 / 03$ \\
\hline 371 & 150636.32 & 383824.13 & 14.6 & $1 \mathrm{~A}$ & $07 / 03$ & 424 & 150632.17 & 383815.50 & 11.6 & 1B & $07 / 03$ \\
\hline 372 & 150636.28 & 383824.20 & 15 & $1 \mathrm{~A}$ & $07 / 03$ & 425 & 150632.67 & 383815.28 & 11 & 1B & $07 / 03$ \\
\hline 373 & 150636.57 & 383824.32 & 13.3 & $1 \mathrm{~A}$ & $07 / 03$ & 426 & 150627.34 & 383822.26 & 17.6 & $1 \mathrm{~B}$ & $07 / 03$ \\
\hline 374 & 150636.20 & 383824.33 & 14.9 & $1 \mathrm{~A}$ & $07 / 03$ & 427 & 150627.59 & 383822.39 & 17.5 & 1B & $07 / 03$ \\
\hline 375 & 150636.57 & 383824.42 & 13.6 & $1 \mathrm{~A}$ & $07 / 03$ & 428 & 150627.43 & 383822.52 & 15.7 & 1B & $07 / 03$ \\
\hline 376 & 150636.20 & 383824.33 & 15.1 & $1 \mathrm{~A}$ & $07 / 03$ & 429 & 150626.10 & 383820.44 & 16.6 & 1B & $07 / 03$ \\
\hline 377 & 150636.57 & 383824.49 & 13.7 & $1 \mathrm{~A}$ & $07 / 03$ & 430 & 150626.56 & 383821.32 & 16.6 & $1 \mathrm{~B}$ & $07 / 03$ \\
\hline
\end{tabular}




\begin{tabular}{cccccc}
\hline 431 & 150626.27 & 383821.77 & 16.4 & $1 \mathrm{~B}$ & $07 / 03$ \\
432 & 150623.08 & 383817.85 & 16.3 & $1 \mathrm{~B}$ & $07 / 03$ \\
433 & 150623.37 & 383818.17 & 17.1 & $1 \mathrm{~B}$ & $07 / 03$ \\
434 & 150623.45 & 383818.17 & 17.5 & $1 \mathrm{~B}$ & $07 / 03$ \\
435 & 150623.41 & 383818.40 & 21 & $1 \mathrm{~B}$ & $07 / 03$ \\
436 & 150624.58 & 383823.72 & 21.2 & $1 \mathrm{~B}$ & $07 / 03$ \\
437 & 150634.63 & 383823.45 & 15.5 & $1 \mathrm{~B}$ & $07 / 03$ \\
438 & 150634.09 & 383823.42 & 14 & $1 \mathrm{~B}$ & $07 / 03$ \\
439 & 150634.25 & 383823.35 & 14 & $1 \mathrm{~B}$ & $07 / 03$ \\
440 & 150634.25 & 383823.29 & 13.6 & $1 \mathrm{~B}$ & $07 / 03$ \\
441 & 150634.38 & 383823.06 & 13.6 & $1 \mathrm{~B}$ & $07 / 03$ \\
442 & 150634.92 & 383823.81 & 16.2 & $1 \mathrm{~B}$ & $07 / 03$ \\
443 & 150634.88 & 383823.87 & 16.2 & $1 \mathrm{~B}$ & $07 / 03$ \\
444 & 150634.59 & 383823.81 & 17.2 & $1 \mathrm{~B}$ & $07 / 03$ \\
445 & 150634.92 & 383823.87 & 16.2 & $1 \mathrm{~B}$ & $07 / 03$ \\
446 & 150634.88 & 383823.90 & 16.5 & $1 \mathrm{~B}$ & $07 / 03$ \\
447 & 150636.32 & 383823.77 & 13.1 & $1 \mathrm{~B}$ & $07 / 03$ \\
448 & 150636.61 & 383823.94 & 12.2 & $1 \mathrm{~B}$ & $07 / 03$ \\
449 & 150636.57 & 383824.23 & 12.2 & $1 \mathrm{~B}$ & $07 / 03$ \\
450 & 150635.99 & 383824.33 & 14.5 & $1 \mathrm{~B}$ & $07 / 03$ \\
451 & 150635.50 & 383823.29 & 14.2 & $1 \mathrm{~B}$ & $07 / 03$ \\
452 & 150638.44 & 383827.08 & 20.3 & $1 \mathrm{~B}$ & $07 / 03$ \\
453 & 150637.08 & 383832.66 & 31.6 & $1 \mathrm{~B}$ & $07 / 03$ \\
454 & 150637.08 & 383832.63 & 31.7 & $1 \mathrm{~B}$ & $07 / 03$ \\
455 & 150617.78 & 383814.06 & 22.6 & $1 \mathrm{~B}$ & $07 / 03$ \\
456 & 150618.19 & 383814.32 & 23 & $1 \mathrm{~B}$ & $07 / 03$ \\
457 & 150617.03 & 383814.22 & 20.1 & $1 \mathrm{~B}$ & $07 / 03$ \\
458 & 150636.61 & 383823.90 & 18.8 & $1 \mathrm{~B}$ & $07 / 03$ \\
459 & 150620.91 & 383809.45 & 12.4 & $1 \mathrm{~B}$ & $07 / 03$ \\
460 & 150620.83 & 383809.61 & 12.4 & $1 \mathrm{~B}$ & $07 / 03$ \\
461 & 150614.83 & 383810.13 & 15.2 & $1 \mathrm{~B}$ & $07 / 03$ \\
\hline & & & & &
\end{tabular}

\section{1C 07/03}

\begin{tabular}{cccccc} 
No. & Long & Lat & Depth & Class & Date \\
\hline 462 & 150638.74 & 383806.06 & 26.9 & $1 \mathrm{C}$ & $07 / 03$ \\
463 & 150638.94 & 383805.77 & 29 & $1 \mathrm{C}$ & $07 / 03$ \\
464 & 150636.00 & 383802.82 & 6.6 & $1 \mathrm{C}$ & $07 / 03$ \\
465 & 150636.00 & 383802.78 & 6 & $1 \mathrm{C}$ & $07 / 03$ \\
466 & 150641.18 & 383808.36 & 27.4 & $1 \mathrm{C}$ & $07 / 03$ \\
467 & 150641.18 & 383808.85 & 27.4 & $1 \mathrm{C}$ & $07 / 03$ \\
468 & 150642.18 & 383814.23 & 11 & $1 \mathrm{C}$ & $07 / 03$ \\
469 & 150642.31 & 383814.36 & 11.2 & $1 \mathrm{C}$ & $07 / 03$ \\
470 & 150642.89 & 383814.36 & 11.2 & $1 \mathrm{C}$ & $07 / 03$ \\
471 & 150631.72 & 383815.76 & 11.7 & $1 \mathrm{C}$ & $07 / 03$ \\
472 & 150632.09 & 383815.57 & 11.9 & $1 \mathrm{C}$ & $07 / 03$ \\
473 & 150632.26 & 383815.41 & 11.2 & $1 \mathrm{C}$ & $07 / 03$ \\
474 & 150627.34 & 383822.29 & 17.5 & $1 \mathrm{C}$ & $07 / 03$
\end{tabular}

\begin{tabular}{cccccc}
475 & 150627.14 & 383822.39 & 18.2 & $1 \mathrm{C}$ & $07 / 03$ \\
476 & 150628.71 & 383822.42 & 14.5 & $1 \mathrm{C}$ & $07 / 03$ \\
477 & 150627.59 & 383822.42 & 17.4 & $1 \mathrm{C}$ & $07 / 03$ \\
478 & 150628.71 & 383822.42 & 14.4 & $1 \mathrm{C}$ & $07 / 03$ \\
479 & 150627.97 & 383822.52 & 16.5 & $1 \mathrm{C}$ & $07 / 03$ \\
480 & 150627.47 & 383822.65 & 16.7 & $1 \mathrm{C}$ & $07 / 03$ \\
481 & 150626.06 & 383820.86 & 17.2 & $1 \mathrm{C}$ & $07 / 03$ \\
482 & 150626.02 & 383821.97 & 17.2 & $1 \mathrm{C}$ & $07 / 03$ \\
483 & 150623.08 & 383817.98 & 16.5 & $1 \mathrm{C}$ & $07 / 03$ \\
484 & 150624.11 & 383818.14 & 17.6 & $1 \mathrm{C}$ & $07 / 03$ \\
485 & 150624.08 & 383823.72 & 22.2 & $1 \mathrm{C}$ & $07 / 03$ \\
486 & 150624.12 & 383823.88 & 21.8 & $1 \mathrm{C}$ & $07 / 03$ \\
487 & 150634.88 & 383823.58 & 15.7 & $1 \mathrm{C}$ & $07 / 03$ \\
488 & 150634.09 & 383823.35 & 13.8 & $1 \mathrm{C}$ & $07 / 03$ \\
489 & 150632.77 & 383823.26 & 12.6 & $1 \mathrm{C}$ & $07 / 03$ \\
490 & 150634.83 & 383823.13 & 13.8 & $1 \mathrm{C}$ & $07 / 03$ \\
491 & 150634.75 & 383823.09 & 13.5 & $1 \mathrm{C}$ & $07 / 03$ \\
492 & 150634.75 & 383823.06 & 13 & $1 \mathrm{C}$ & $07 / 03$ \\
493 & 150634.21 & 383823.00 & 13 & $1 \mathrm{C}$ & $07 / 03$ \\
494 & 150634.21 & 383821.83 & 10.9 & $1 \mathrm{C}$ & $07 / 03$ \\
495 & 150634.63 & 383823.74 & 16.7 & $1 \mathrm{C}$ & $07 / 03$ \\
496 & 150632.52 & 383823.84 & 13.9 & $1 \mathrm{C}$ & $07 / 03$ \\
497 & 150632.68 & 383824.00 & 14.3 & $1 \mathrm{C}$ & $07 / 03$ \\
498 & 150635.58 & 383823.68 & 14.9 & $1 \mathrm{C}$ & $07 / 03$ \\
499 & 150636.20 & 383823.94 & 14.2 & $1 \mathrm{C}$ & $07 / 03$ \\
500 & 150635.83 & 383824.00 & 15.3 & $1 \mathrm{C}$ & $07 / 03$ \\
501 & 150635.83 & 383824.00 & 15.3 & $1 \mathrm{C}$ & $07 / 03$ \\
502 & 150635.79 & 383824.07 & 15 & $1 \mathrm{C}$ & $07 / 03$ \\
503 & 150635.70 & 383824.13 & 15.1 & $1 \mathrm{C}$ & $07 / 03$ \\
504 & 150636.03 & 383824.26 & 13.8 & $1 \mathrm{C}$ & $07 / 03$ \\
505 & 150635.95 & 383824.46 & 14.7 & $1 \mathrm{C}$ & $07 / 03$ \\
506 & 150635.71 & 383825.33 & 17.9 & $1 \mathrm{C}$ & $07 / 03$ \\
507 & 150635.42 & 383825.36 & 16.9 & $1 \mathrm{C}$ & $07 / 03$ \\
508 & 150635.62 & 383825.49 & 17.9 & $1 \mathrm{C}$ & $07 / 03$ \\
509 & 150634.96 & 383823.45 & 15.2 & $1 \mathrm{C}$ & $07 / 03$ \\
510 & 150638.44 & 383827.11 & 20.2 & $1 \mathrm{C}$ & $07 / 03$ \\
511 & 150638.56 & 383827.28 & 21 & $1 \mathrm{C}$ & $07 / 03$ \\
512 & 150638.36 & 383827.24 & 20.5 & $1 \mathrm{C}$ & $07 / 03$ \\
513 & 150638.11 & 383827.02 & 19.2 & $1 \mathrm{C}$ & $07 / 03$ \\
514 & 150639.69 & 383832.40 & 32.7 & $1 \mathrm{C}$ & $07 / 03$ \\
515 & 150616.91 & 383814.32 & 20.1 & $1 \mathrm{C}$ & $07 / 03$ \\
516 & 150621.00 & 383809.42 & 12.3 & $1 \mathrm{C}$ & $07 / 03$ \\
\hline & & & & &
\end{tabular}

\section{C $2 \mathrm{C} \mathrm{07/03}$}

No. Long Lat Depth Class Date

$\begin{array}{llllll}517 & 150638.78 & 383805.73 & 29 & 2 \mathrm{~B} & 07 / 03\end{array}$

$\begin{array}{llllll}518 & 150636.08 & 383802.72 & 5.9 & 2 \mathrm{~B} & 07 / 03\end{array}$ 


\begin{tabular}{|c|c|c|c|c|c|c|c|c|c|c|c|}
\hline 519 & 150636.04 & 383800.41 & 24.6 & $2 \mathrm{~B}$ & $07 / 03$ & 561 & 150634.09 & 383823.35 & 13.8 & 1B & $12 / 03$ \\
\hline 520 & 150636.41 & 383802.33 & 7 & $2 \mathrm{~B}$ & $07 / 03$ & 562 & 150634.09 & 383823.45 & 13.9 & 1B & $12 / 03$ \\
\hline 521 & 150619.61 & 383825.22 & 27 & $2 \mathrm{~B}$ & $07 / 03$ & 563 & 150634.59 & 383823.81 & 16.8 & 1B & $12 / 03$ \\
\hline 522 & 150620.81 & 383823.98 & 25.9 & $2 \mathrm{~B}$ & $07 / 03$ & 564 & 150634.09 & 383824.00 & 11.7 & 1B & $12 / 03$ \\
\hline 523 & 150636.04 & 383800.41 & 24.6 & $2 \mathrm{~B}$ & $07 / 03$ & 565 & 150634.88 & 383825.27 & 14.9 & 1B & $12 / 03$ \\
\hline 524 & 150636.41 & 383802.33 & 7 & $2 \mathrm{~B}$ & $07 / 03$ & 566 & 150636.70 & 383824.71 & 14 & 1B & $12 / 03$ \\
\hline 525 & 150619.61 & 383825.22 & 27 & $2 \mathrm{~B}$ & $07 / 03$ & 567 & 150636.70 & 383824.68 & 13.9 & 1B & $12 / 03$ \\
\hline 526 & 150620.81 & 383823.98 & 25.9 & $2 \mathrm{~B}$ & $07 / 03$ & 568 & 150636.57 & 383824.49 & 13.7 & 1B & $12 / 03$ \\
\hline \multicolumn{2}{|c|}{ EC 1A $12 / 03$} & \multirow{3}{*}{ Lat } & \multirow{3}{*}{ Depth } & \multirow{3}{*}{ Class } & \multirow{3}{*}{ Date } & 569 & 150636.28 & 383824.10 & 14.4 & 1B & $12 / 03$ \\
\hline 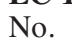 & Long & & & & & 570 & 150635.04 & 383824.00 & 16.5 & 1B & $12 / 03$ \\
\hline & & & & & & 5 & 5.16 & 23.94 & 14.4 & 1B & $12 / 03$ \\
\hline 528 & 150634.58 & 383822.83 & 12.4 & $1 \mathrm{~A}$ & $12 / 03$ & 572 & 150636.16 & 383823.94 & 14.4 & 1B & $12 / 03$ \\
\hline 529 & 150634.67 & 383822.80 & 12.4 & $1 \mathrm{~A}$ & $12 / 03$ & 573 & 150635.04 & 383823.16 & 13.5 & 1B & $12 / 03$ \\
\hline 530 & 150634.79 & 383822.87 & 12.5 & $1 \mathrm{~A}$ & $12 / 03$ & 574 & 150634.96 & 383822.83 & 12.8 & 1B & $12 / 03$ \\
\hline 531 & 150634.34 & 383822.90 & 12.2 & $1 \mathrm{~A}$ & $12 / 03$ & 575 & 150638.23 & 383826.53 & 17.9 & 1B & $12 / 03$ \\
\hline 532 & 150634.83 & 383822.87 & 12.1 & $1 \mathrm{~A}$ & $12 / 03$ & 576 & 150638.07 & 383826.85 & 19.2 & $1 \mathrm{~B}$ & $12 / 03$ \\
\hline 533 & 150634.38 & 383823.06 & 13.1 & $1 \mathrm{~A}$ & $12 / 03$ & 577 & 150639.80 & 383827.66 & 22.8 & 1B & $12 / 03$ \\
\hline 534 & 150633.80 & 383823.32 & 13 & $1 \mathrm{~A}$ & $12 / 03$ & \multicolumn{2}{|c|}{$1 \mathrm{C} 12 / 03$} & \multirow[b]{2}{*}{ Lat } & \multirow[b]{2}{*}{ Depth } & \multirow[b]{2}{*}{ Class } & \multirow[b]{2}{*}{ Date } \\
\hline 535 & $\begin{array}{l}150634.63 \\
150634.13\end{array}$ & 383823.52 & $\begin{array}{l}15.7 \\
13.1\end{array}$ & $1 \mathrm{~A}$ & $12 / 03$ & No. & Long & & & & \\
\hline 537 & 150636.66 & 383824.68 & 14 & $1 \mathrm{~A}$ & $12 / 03$ & 578 & 150 & 38 & 12.7 & $1 \mathrm{C}$ & $12 / 03$ \\
\hline 538 & 150636.53 & 383824.45 & 14.1 & $1 \mathrm{~A}$ & $12 / 03$ & 579 & 150 & 383825.27 & 17.3 & $1 \mathrm{C}$ & $12 / 03$ \\
\hline 539 & 150636.49 & 383824.42 & 13.6 & $1 \mathrm{~A}$ & $12 / 03$ & 580 & 150635.99 & 383824.33 & 15.1 & $1 \mathrm{C}$ & $12 / 03$ \\
\hline 540 & 150636.53 & 383824.36 & 13.6 & $1 \mathrm{~A}$ & $12 / 03$ & 581 & 150635.99 & 383824.33 & 14.8 & $1 \mathrm{C}$ & $12 / 03$ \\
\hline 541 & 150636.16 & 383824.33 & 15.1 & $1 \mathrm{~A}$ & $12 / 03$ & 582 & 150636.61 & 383824.16 & 12.9 & $1 \mathrm{C}$ & $12 / 03$ \\
\hline 542 & 150636.53 & 383824.29 & 13.3 & $1 \mathrm{~A}$ & $12 / 03$ & 583 & 150635.83 & 383824.00 & 15 & $1 \mathrm{C}$ & $12 / 03$ \\
\hline 543 & 150636.16 & 383824.33 & 15.1 & $1 \mathrm{~A}$ & $12 / 03$ & 584 & 150636.28 & 383823.81 & 13.7 & $1 \mathrm{C}$ & $12 / 03$ \\
\hline 544 & 150636.24 & 383824.07 & 14.2 & $1 \mathrm{~A}$ & $12 / 03$ & 585 & 150639.64 & 383826.76 & 19.4 & $1 \mathrm{C}$ & $12 / 03$ \\
\hline 545 & 150636.28 & 383823.90 & 14.1 & $1 \mathrm{~A}$ & $12 / 03$ & 586 & 150638.07 & 383826.85 & 19.2 & $1 \mathrm{C}$ & $12 / 03$ \\
\hline 546 & 150636.24 & 383823.94 & 14.1 & $1 \mathrm{~A}$ & $12 / 03$ & 587 & 150638.11 & 383826.95 & 19.3 & $1 \mathrm{C}$ & $12 / 03$ \\
\hline 547 & 150634.88 & 383823.81 & 16.2 & $1 \mathrm{~A}$ & $12 / 03$ & 588 & 150638.11 & 383827.02 & 19.4 & $1 \mathrm{C}$ & $12 / 03$ \\
\hline 548 & 150634.88 & 383823.78 & 16 & $1 \mathrm{~A}$ & $12 / 03$ & 589 & 150638.48 & 383827.11 & 20 & $1 \mathrm{C}$ & $12 / 03$ \\
\hline 549 & 150634.96 & 383823.61 & 15.6 & $1 \mathrm{~A}$ & $12 / 03$ & 590 & 150637.98 & 383827.24 & 20.1 & $1 \mathrm{C}$ & $12 / 03$ \\
\hline 550 & 150635.29 & 383823.55 & 14.9 & $1 \mathrm{~A}$ & $12 / 03$ & 591 & 150638.44 & 383827.28 & 20.5 & $1 \mathrm{C}$ & $12 / 03$ \\
\hline 551 & 150635.24 & 383823.54 & 14.8 & $1 \mathrm{~A}$ & $12 / 03$ & 592 & 150640.01 & 383827.53 & 21.9 & $1 \mathrm{C}$ & $12 / 03$ \\
\hline 552 & 150635.26 & 383823.52 & 14.7 & $1 \mathrm{~A}$ & $12 / 03$ & 593 & 150634.92 & 383825.27 & 14.5 & $1 \mathrm{C}$ & $12 / 03$ \\
\hline 553 & 150634.83 & 383822.87 & 12.7 & $1 \mathrm{~A}$ & $12 / 03$ & \multicolumn{2}{|c|}{ A $12 / 03$} & \multirow[b]{2}{*}{ Lat } & \multirow[b]{2}{*}{ Depth } & \multirow[b]{2}{*}{ Class } & \multirow[b]{2}{*}{ Date } \\
\hline 554 & 150635.16 & 383822.90 & 12.2 & $1 \mathrm{~A}$ & $12 / 03$ & No. & Long & & & & \\
\hline 555 & 150638.23 & 383826.53 & 17.7 & & & & 150 & 383 & 13 & 2 & $12 / 03$ \\
\hline 556 & 150637.94 & 383826.63 & 18.6 & $1 \mathrm{~A}$ & $12 / 03$ & & & 3838 & 13. & $2 \mathrm{~A}$ & $12 / 03$ \\
\hline 557 & 150640.80 & 383826.66 & 19.3 & $1 \mathrm{~A}$ & $12 / 03$ & 595 & 150634.09 & 383823.87 & 13.6 & $2 \mathrm{~A}$ & $12 / 03$ \\
\hline 558 & 150639.64 & 383826.72 & 19.6 & $1 \mathrm{~A}$ & $12 / 03$ & 596 & 150634.63 & 383824.46 & 15.2 & $2 \mathrm{~A}$ & $12 / 03$ \\
\hline \multicolumn{2}{|c|}{ 1B $12 / 03$} & & & & & 597 & 50635 & 383823.81 & 15.4 & $2 \mathrm{~A}$ & $12 / 03$ \\
\hline No. & Long & Lat & Depth & Class & Date & 598 & 150635.29 & 383823.85 & 15.5 & $2 \mathrm{~A}$ & $12 / 03$ \\
\hline & & & & & & 599 & 150635.37 & 383823.71 & 15.2 & $2 \mathrm{~A}$ & $12 / 03$ \\
\hline 559 & 150634.75 & 383822.74 & 12.6 & 1B & $12 / 03$ & 600 & 150635.08 & 383823.71 & 15.6 & $2 \mathrm{~A}$ & $12 / 03$ \\
\hline 560 & 150634.17 & 383823.00 & 12.7 & $1 \mathrm{~B}$ & $12 / 03$ & 601 & 150636.98 & 383821.53 & 8.8 & $2 \mathrm{~A}$ & $12 / 03$ \\
\hline
\end{tabular}




\begin{tabular}{|c|c|c|c|c|c|c|c|c|c|c|c|}
\hline $12 / 03$ & & & & & & 603 & 150632.48 & 383823.84 & 13.9 & $2 \mathrm{~B}$ & $12 / 03$ \\
\hline No. & Long & Lat & Depth & Class & Date & 604 & 150632.68 & 383824.00 & 13.8 & $2 \mathrm{~B}$ & $12 / 03$ \\
\hline 602 & 150631.65 & 383823.84 & 14.8 & $2 B$ & $12 / 03$ & $\begin{array}{l}605 \\
606\end{array}$ & $\begin{array}{l}150636.78 \\
150635.12\end{array}$ & $\begin{array}{l}383825.56 \\
383823.74\end{array}$ & $\begin{array}{c}16 \\
15.7\end{array}$ & $\begin{array}{l}2 \mathrm{~B} \\
2 \mathrm{~B}\end{array}$ & $\begin{array}{l}12 / 03 \\
12 / 03\end{array}$ \\
\hline
\end{tabular}

\section{REFERENCES}

ANZIDEI, M. (2000): Rapid bathymetric surveys in marine volcano areas: a case study in Panarea aera, Phys. Chem. Earth A, 25 (1), 77-80.

AnZidei, M., P. BAldi, G. Casula, F. Riguzzi and L. Surace (1995): La rete TyrGeoNet, Boll. Geod. Sci. Affini, LIV (2), pp. 120.

AnZidei, M., A. Esposito, G. Giordano and A. Benini (2003): Diving in the Panarea volcanic complex (Aeolian Islands, Italy), in Cities on Volcanoes 3, July 1418, 2003, Hilo, Hawaii.

Anzidei, M., A. Esposito, A. Pesci and E. Serpelloni (2004a): The 2002-2003 crisis of the Panarea volcanic complex (Aeolian Islands, Italy): new volcanologgical, geodetic and bathymetric data, in GNV General Assembly, 20-22 December, Napoli, Italy (abstract).

Anzidei, M., M.L. Carapezza, R. Cioni, A. Esposito, G. Giordano, M. Guidi, M. Lelli and C. Piccione (2004b): Indagini geologiche e geochimiche nella zona ad est di Panarea sede delle emissioni anomale di gas del Novembre 2002, in GNV General Assembly, 20-22 December, Napoli, Italy (abstract).

Calanchi, N., B. CAPACCIONi, M. Martini, F. TASsi and L. VAlentini (1995): Submarine gas-emission from Panarea Island Aeolian Archipelago: distribution of inorganic and organic compounds and inferences about source conditions, Acta Vulcanol., 7 (1), 43-48.

Calanchi, N., C.A. Tranne, F. Lucchini, P.L. Rossi and I.M. VILLA (1999): Explanatory notes to the geological map (1:10000) of Panarea and Basiluzzo islands (Aeolian Arc, Italy), Acta Vulcanol., 11 (2), 223-243.

Calanchi, N., A. Peccerillo, C.A.Tranne, F. Lucchini, P.L. Rossi, P. Kempton, M. BARBIERI and T.W. Wu (2002): Petrology and geochemistry of volcanic rocks from the Island of Panarea: implications for mantle evolution beneath the Aeolian Island Arc (Southern Tyrrhenian Sea), J. Volcanol. Geotherm. Res., 115, 367-395.

Caliro, S., A. Caracausi, G. Chiodini, M. DitTa, F. ItalIANo, M. Longo, C. Minopoli, P.M. NucCio, A. PAOnITA and A. Rizzo (2004): Evidence of a new magmatic input to the quiescent volcanic edifice of Panarea, Aeolian Islands, Italy, Geophys. Res. Lett., 31, L07619, doi: 10.1029/2003GL019359

Caracausi, A., M. Ditta, F. Italiano, M. Longo, P.M. NuCCIO and A. PAONITA (2005): Massive submarine gas output during the volcanic unrest off Panarea Island (Aeolian arc, Italy): inferences for explosive conditions, Geochem. J. (in press).

CARIS (2000): CARIS-HIPS (Hydrographic Information Processing System) and SIPS Professional v. 5.2 Software User Guide: MA-HIPS-UG-02-02 (on line http://www.caris.com/).

Chiarabba, C., L. Jovane and R. Di Stefano (2005): A new view of Italian seismicity using 20 years of instrumental seismicity, Tectonophysics, 395, 251-268.

D'Agostino, N. and G. SelvagGi (2004): Crustal motion along the Eurasia-Nubia plate boundary in the Calabria Arc and Sicily and active extension in the Messina Straits from GPS measurements, J. Geophys. Res., 109 (B11402), doi: 10.1029/2004JB002998.

De Astis, G., G. Ventura and G. Vilardo (2003): Geodynamic significance of the Aeolian volcanism (Southern Tyrrhenian Sea, Italy) in light of structural, seismological and geochemical data, Tectonics, 22 (4), 1040, doi: 10.1029/2003TC001506.

Dolomieu, D. (1783): Voyage aux Iles de Lipari Fait en 1781 ou Notice sur les Iles Aeoliennes, Paris, pp. 208.

Dumas, A. (1860): Dove il Vento Suona. Viaggio nelle Isole Eolie (Ed. Pungitopo, Marina di Patti, Messina).

Esposito, A., G. Giordano and M. Anzidei (2005): The 2002-2003 submarine gas eruption at Panarea Island (Aeolian Archipelago, Italy): structure and volcanology of the seafloor and implications for hazard evaluation, Mar. Geol. (submitted).

FAlsaperla, S., G. LANZAFAme, V. Longo and S. SpampinaTO (1999): Regional stress field in the area of Stromboli (Italy): insights into structural data and crustal tectonic earthquakes, J. Volcanol. Geotherm. Res., 88, 147-166.

Ferrara, F. (1810): Campi Flegrei della Sicilia e delle Isole che le sono intorno (Messina), pp. 424.

Gabbianelli, G., P.Y. Gillot, G. Lanzafame, C. RomagNOLI and P.L. Rossi (1990): Tectonic and volcanic evolution of Panarea (Aaeolian Island, Italy), Mar. Geol., 92, 312-326.

Gabbianelli, G., C. Romagnoli, P.L. Rossi and N. CAlanche (1993): Marine Geology of Panarea-Stromboli area, Aeolian Archipelago, Southeastern Tyrrhenian Sea, Acta Vulcanol., 3, 11-20.

GAMBERI, F., P.M. MARANI and C. SAVELLI (1997): Tectonic volcanic and hydrothermal features of submarine portion of Aeolian arc (Tyrrhenian Sea), Mar. Geol., 140, 167-181.

Hollestein, Ch., H.G. Kahle, A. Geiger, S. Jenny, S. GoEs and D. Giardini (2003): New GPS constraints on the Africa-Eurasia plate boundary zone in Southern Ita1y, Geophys. Res. Lett., 30 (18), 1935, doi: 10.1029/ /2003GL017554.

Houel, L. (1782): Voyage Pittoressque des Isles de Sicilie, de Malte et de Lipari ect., Paris.

ItAliano, F. and P.M. Nuccio (1991): Geochemical investigations of submarine volcanic exhalations to the eat Panarea, Aeolian Islands, Italy, J. Volcanol. Geotherm. Res., 46, 125-141.

Lucchi, F., C.A. Tranne, N. Calanchi, J. Keller and P.L. Rossi (2003): Geological Map of Panarea and Minor Islets (Aaeolian Islands), (Università di Bologna, INGV, LAC Firenze). 
Luigi Salvatore D’Austria (1895): Die Liparischen, Inseln vierter Heft: Panaris (new edition by P. PAINO, Lipari (ME), 1977).

MerCAlLi, G. (1883): Vulcani e fenomeni Vulcanici, in $G e$ ologia d'Italia, edited by G. NeGRI, A. STOPPANI and G. MERCALli (Milano), 3rd part, pp. 374.

Romano, R. (1973): Le isole di Panarea e Basiluzzo, Riv. Miner. Siciliana, 139-141, 49-86.

Saccarotti, G., D. Galluzzo, M. La Rocca, E. Del Pezzo and D. PATANÈ (2003): Monitoraggio dell'attività sismica a Panarea, in GNV General Assembly, 9-11 June, Roma, Italy.

Serpelloni, E., M. Anzidei, P. Baldi, G. Casula and A. GALVANI (2005): Crustal velocity and strain-rate fields in Italy and surrounding regions: new results from the analysis of permanent and non-permanent GPS networks, Geophys. J. Int. (in press).

SpallanZani, L. (1825): Viaggi alle Due Sicilie e in Alcune Parti dell'Appennino (Milano), tomo I.

SGA (Storia Geofisica e Ambiente) (1996): Fenomeni vulcanici nell'Arcipelago delle Eolie dall'antichità al XX secolo, Studio di Fattibilità RPT 156,96 (Bologna, Italy).

Tallarico, A., M. Dragoni, M. Anzidei and A. EsPosito (2003): Modeling long-term ground deformation due to the cooling of a magma chamber: case of Basiluzzo Island, Aeolian Islands, Italy, J. Geophys. Res., 108 (B 12), 2568, doi: 10.1029/2002JB002376.

(received January 13, 2005; accepted June 21, 2005) 